\title{
Revisions of conodont biostratigraphy across the Silurian-Devonian boundary
}

\author{
Peter CARLS, LADISLAV SLAVÍK \& José IgnACIO VALENZUela-Ríos
}

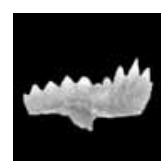

\begin{abstract}
The current conodont biozonation near the Silurian/Devonian boundary includes problematic biozones and is revised. Global applications of the zonal concepts concerning the current standard conodont zones eosteinhornensis, remscheidensis, detorta, and woschmidti are revised. New correlations are based on conodont faunas from the Požáry section (the stratotype of the Prrídolí Series, Barrandian) and the Elbersreuth Orthoceratid Limestone (Frankenwald); they enable correlations with Baltic conodont faunas. The new data show that the eosteinhornensis Zone s.s. begins amid the Prrídolí. The Delotaxis "detorta" plexus is not limited to the final Prídolí because it enters before the eosteinhornensis Zone. Accordingly, the use of a detorta Zone for global correlation is not recommended. The type stratum of the very particular Icriodus woschmidti is much younger than the entry of Icriodus postwoschmidti in Podolia. A succession of a woschmidti Zone and a postwoschmidti Zone in the early Lochkovian is problematic. Three new spathognathodontid species with stratigraphic potential: Zieglerodina? ivochlupaci sp. nov., Zieglerodina? klonkensis sp. nov. and Zieglerodina? zellmeri sp. nov. are described. $\bullet$ Key words: Silurian/Devonian boundary, Conodont zonation, Conodont biostratigraphy, Barrandian, Frankenwald, Eastern Baltic.
\end{abstract}

CARLS, P., SLAVÍK, L. \& VAlENZUElA-RíOS, J.I. 2007. Revisions of conodont biostratigraphy across the Silurian-Devonian boundary. Bulletin of Geosciences 82(2), 145-164 (8 figures, 1 table). Czech Geological Survey, Prague. ISSN 1214-1119. Manuscript received January 10, 2007; accepted in revised form May 9, 2007; issued June 30, 2007. • DOI 10.3140/bull.geosci.2007.02.145

Peter Carls, Institut für Umweltgeologie, Technische Universität Braunschweig, Pockelsstrasse 3, D-38023 Braunschweig, Germany • Ladislav Slavik (corresponding author), Academy of Sciences of the Czech Republic, Institute of Geology, v.v.i., Rozvojová 269, CZ-16502 Praha, Czech Republic; slavik@gli.cas.cz・José Ignacio Valenzuela-Ríos, University of València, Department of Geology, C/. Dr. Moliner 50, E-46100 Burjassot, Spain; Jose.I.Valenzuela@uv.es

Work on the biostratigraphy of the late Silurian and earliest Devonian by means of conodont successions from Bohemia and other regions, has revealed that the literature contains several problematic aspects of identification and zonation. Conodonts are, undoubtedly, important biostratigraphic tools in the correlation of the Silurian/Devonian boundary and adjacent strata. However, intense work on conodont correlation during past decades brought, beside new and valuable data, also many problems. The Silurian/Devonian boundary is fixed in bed 20 of the limitotype section of Klonk (Barrandian, Czechia) where graptolites abound. The identification and interpretation of certain graptolites concerned have hardly been disputed, whereas Klonk conodonts have been involved in errors of identification and correlation. Jeppsson $(1988,1989)$ has described the conodont succession in the late Přídolí of the Klonk section. But in this section many beds furnish poorly informative conodont faunas. Therefore the present study used the Požáry section SW of Prague (Fig. 1, for description see Kř́ž et al. 1986), where conodonts are more abundant.
Discrepancies in conodont correlation are propagated mainly through the uncritical application of formalisms of biostratigraphic zonation. Basically, correlation does not need a zonation, but a good zonation, of course, can promote communication. On the other hand, a zonation based on undue taxonomy can create great confusion. This can be recognized in the history of the conodont zonations that have been proposed for the late Silurian (see Fig. 2) and the early Devonian (Přídolí to early Lochkovian). Problems in conodont taxonomy and formalisms in zonation and stratigraphy have escalated in this interval. The main purpose of this paper is to elucidate the succession of certain guide conodonts below and across the S/D system boundary and to compare conodont successions from different regions.

\section{Remarks on nomenclature}

The generic affiliations of several multielement conodont taxa treated in this text have been changed repea- 


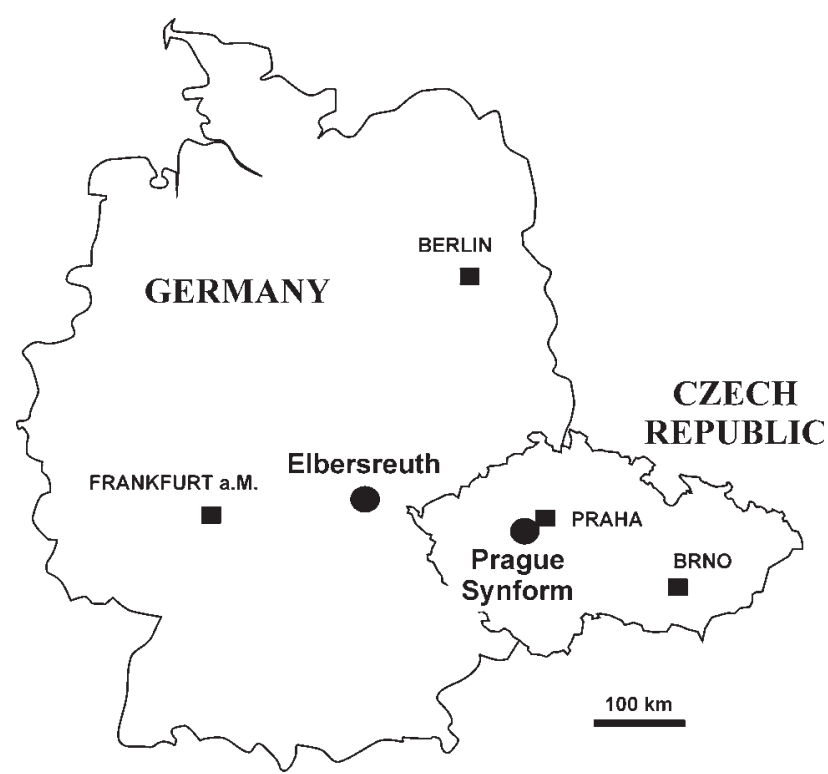

Figure 1. A location map with marked studied areas: the Elbersreuth Orthoceratid Limestone (Frankenwald) and the Požáry Quarries (Barrandian)

tedly.e.g., Spathognathodus crispus Walliser, 1964 was changed to "Ozarkodina" crispa. But its $\mathrm{Pa}$ element is so different from that of the type species, that the inclusion in Ozarkodina is doubtful. As the apparatus of the species crispus Walliser, 1964 is not yet completely known, an erection of a new genus is not yet opportunous. Therefore, "O." crispa can presently not be attributed to an appropriate genus. Jeppsson \& Merrill (1982) have recommended how to designate and how to refer to former binomina, and we follow their proposals where applicable. In certain cases no genus is available, and the repetition of obsolete binominal combinations would be misleading. Then we use only a species name, or we indicate a genus provisionally like "genus W eosteinhornensis".

In Delotaxis the intercalation of small denticles is characteristic for $D$. detorta (Walliser, 1964), but it also occurs in another species: Viira (1999, pl. 4, fig. 10) showed an Sb element with intercalated small denticles that differs from the elegans-detorta stock. Accordingly, Viira refered to a "detorta" plexus that comprises possibly more than one late Silurian Delotaxis with intercalation, not only to detorta. Scarcity of material of Delotaxis elements with intercalation does not yet allow a decision, whether intercalation develops also in the stock of D. silurica (Branson \& Mehl, 1933), in association with whose Sc elements similar Sb without intercalation occur mostly. In order to provide a collective for comparable late Silurian Delotaxis with alternation also beyond D. detorta, a "detorta" plexus is suggested.

\section{Discrepancies within the Silurian-Devonian conodont zonation}

\author{
The eosteinhornensis Zone - problems, \\ definition and stratigraphic validity
}

In 1964, Walliser proposed the first conodont zonation for the Silurian System, including the eosteinhornensis Zone for the entire interval later defined as the Př́idolí. This scheme has since been followed by most authors. The first concept of the index taxon Spathognathodus steinhornensis eosteinhornensis Walliser, 1964 was founded on the broad morphological spectrum of $\mathrm{Pa}$ elements present in the type stratum of this species, namely in bed 40 of the Cellon section (Carnic Alps). A rich sample from this bed has also been used by Murphy et al. (2004). After elimination of the distinct representatives of Spathognathodus inclinatus (Rhodes, 1953) (= Pa element of Wurmiella excavata excavata (Branson \& Mehl, 1933) and its conspecific elements, there remain abundant $\mathrm{Pa}$ elements of various morphologies plus various ramiform and other elements. Among these Pa elements, only some correspond to the holotype of the taxon eosteinhornensis in the features that have been rightly stressed by Jeppsson (1974, p. 38) and by Klapper \& Murphy (1974, p. 42) and which we reiterate as follows: Blade with only moderate size differences between denticles; some denticles near the middle can be fused; basal lobes large, tending to angular and "heart-shaped" outlines, centered clearly behind mid-length of the blade; outer lobe (more rarely also inner lobe) bearing a node or crest. This diagnosis is sufficient to separate the Pa element of the taxon eosteinhornensis within its type stratum. Other Pa elements in the type stratum (essentially characterized by the lack of a node, greater differences in denticles, and a more anterior position of the smaller and rounded ("bell-like" - sensu Jeppsson 1974, p. 39) basal lobes belong to Zieglerodina sp. 40 ( $\mathrm{Pa}$ elements of this taxon, which also occur in bed 40 of the Cellon section, were first figured by Carls 1975, pl. 2, figs 16-18 from the very basal Devonian of Aragón under the identification of $\mathrm{Oz}$. remscheidensis; provisionally, it is here termed Zieglerodina sp. 40 aff. remscheidensis). The generic attribution to Zieglerodina Murphy et al. (2004) is supported by the association both in Aragón and at Cellon to elements like those figured by Murphy et al. (2004, fig. $3-25(\mathrm{Sb}), 29(\mathrm{~Pb})$, 30(Sa), 31(Sa), 32(Sc). Sa elements that cannot be distinguished from these occur not only in the type stratum of Z. remscheidensis, but are also associated with Pa elements of Z. repetitor Carls \& Gandl, 1969 and other Přídolí and Lochkovian species of Zieglerodina that are still unnamed (cf. Murphy et al. 2004, fig. 3). Pa elements of Zieglerodina sp. 40 range up to the initial Lochkovian (Carls 1975, pl. 2, figs 16-18). The Pa elements of the taxon eosteinhornensis can be grouped with the shorter and higher $\mathrm{Pb}$ ele- 


\begin{tabular}{|c|c|c|c|c|c|c|}
\hline \multirow{2}{*}{ 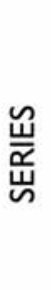 } & CARNIC ALPS & NEVADA & "GLOBAL" & AUSTRALIA & "GLOBAL" & $\begin{array}{l}\text { Graptolite } \\
\text { Standard } \\
\text { Zonation }\end{array}$ \\
\hline & $\begin{array}{l}\text { Walliser } \\
(1964)\end{array}$ & $\begin{array}{l}\text { Klapper } \\
\text { \& Murphy } \\
(1975)\end{array}$ & $\begin{array}{c}\text { Aldridge } \\
\text { \& Schönlaub } \\
(1989)\end{array}$ & $\begin{array}{l}\text { Simpson } \\
\text { (1995) }\end{array}$ & $\begin{array}{c}\text { Silurian Times } \\
\text { No. } 3 \\
(1995)\end{array}$ & $\begin{array}{c}\text { Silurian Times } \\
\text { No. } 3 \\
(1995)\end{array}$ \\
\hline \multirow{4}{*}{$\begin{array}{l}\overline{\bar{O}} \\
\text { 음 } \\
\text { 高 }\end{array}$} & \multirow{4}{*}{$\begin{array}{l}\text { Spathognathodus } \\
\text { steinhornensis } \\
\text { eosteinhornensis }\end{array}$} & \multirow{3}{*}{ eosteinhornensis } & $\begin{array}{l}\text { Icriodus w. } \\
\text { woschmidti } \\
\text { (partim) }\end{array}$ & \multirow{2}{*}{ detortus } & $\begin{array}{l}\text { Ozarkodina eost. } \\
\text { - Oulodus el. } \\
\text { detortus }\end{array}$ & \multirow{2}{*}{$\begin{array}{c}\text { bouceki } \\
\text { - transgrediens }\end{array}$} \\
\hline & & & \multirow{3}{*}{$\begin{array}{l}\text { Ozarkodina } \\
\text { remscheidensis } \\
\text { eosteinhornensis }\end{array}$} & & \multirow{3}{*}{$\begin{array}{l}\text { Ozarkodina } \\
\text { remscheidensis } \\
\text { interval Zone }\end{array}$} & \\
\hline & & & & \multirow{2}{*}{ eosteinhornensis } & & $\begin{array}{c}\text { branikensis } \\
\text { - lochkovensis }\end{array}$ \\
\hline & & $\begin{array}{l}\text { Pelekysgnathus } \\
\text { index fauna }\end{array}$ & & & & $\begin{array}{l}\text { parultimus } \\
\text { - ultimus }\end{array}$ \\
\hline
\end{tabular}

Figure 2. Development of the conodont zonation of the Př́idolí (according to selected papers) in relation to the graptolite zones (right column).

ments figured by Murphy et al. (2004, fig. 3 - 26-28). Additional ramiform elements in the same sample that differ from those of Zieglerodina partly belong to eosteinhornensis; the branches of Sc elements in this group do not undulate and develop ledges on the outer side that are absent in Zieglerodina. But there are further taxa that cannot yet be separated conclusively. These remarks may promote the distinction of the index taxon eosteinhornensis and its generic separation from Z. remscheidensis. Provisionally, we allude to the genus only with the term "genus W" because the apparatus composition is not yet certain. The former practice of treating the taxon eosteinhornensis as a subspecies of $Z$. remscheidensis has proved not to apply.

When Walliser (1964) coined the taxon "eosteinhornensis", he considered it as a rather homoeomorphic subspecies of "Spathognathodus" steinhornensis Ziegler, 1956. Later, the latter became the generotype of Criteriognathus Walliser, 1972 which was coined to house the steinhornensis plexus. A synopsis of the subsequent treatment and of presently available materials that had originally been included in the species steinhornensis, may serve to illustrate how the concepts have changed. Herein, we erect new taxa guided by this former experience.

The type material of Spathognathodus steinhornensis Ziegler, 1956 is from Emsian (mid-Zlichovian) beds in the lower part of the Schönau Limestone (Kellerwald, Germany). A diplododellan Sa element is associated to it, which is a distinctive generic feature. Its typical Pa elements bear a node on their outer basal lobe, but the type stratum also contains smaller Pa elements without such a node and with, additionally, a more anterior position of the basal lobes. In a time when "splitting" was considered to be detrimental for conodont taxonomy and biostratigraphy, presence or lack of a node and further slight differences were regarded as subject to intraspecific and even intrasubspecific variability. In the case of the Emsian forms it is now evident that a subdivision is necessary: The earlier Emsian (mainly original late Pragian) taxon miae Bultynck, 1971 that lacks a node, was grouped as an earlier appearing subspecies of $\mathrm{Cr}$. steinhornensis and it was assumed that it overlaps with $\mathrm{Cr}$. steinhornensis in range. But neither intraspecific nor intrageneric coherence with $\mathrm{Cr}$. steinhornensis are warranted: The apparatus of miae is not yet entirely known (the Sa element is unknown) and the overlap is inexistent. In the early to middle Zlichovian of the Mariposas Fm. in Celtiberia there is a succession of three different $\mathrm{Pa}$ elements: miae, a rather small and equidentate unnamed sp. nov. M, and $\mathrm{Cr}$. steinhornensis. The middle one has short overlaps with both others. Thus, it seemed that $\mathrm{Cr}$. steinhornensis included small Pa elements without a node on the basal lobe and had a considerable variability. Although the generic attribution of both older taxa is uncertain, this subdivision can be seen as an example encouraging the "splitting" also of the late Silurian and earliest Devonian populations. As these old populations were formerly included within the species steinhornensis but are excluded even from its genus Criteriognathus, they need proper species, if their genetic independence is recognized. Forms that were lumped in the subspecies "eosteinhornensis" and "remscheidensis" are 
here separated on species level, if their ranges and multielement apparatuses demand this. Indeed, taxa formerly included in the (sub)species remscheidensis are now identified as Lanea Murphy \& Valenzuela-Ríos, 1999 with good biostratigraphic success.

Evidently, the former concept that a considerable variability exists in the Emsian "Spathognathodus" st. steinhornensis has influenced the rather broad concept of the taxon "eosteinhornensis". Walliser (1964), probably in view of the Zlichovian material he had at hand (including miae, sp. nov. M, and steinhornensis), admitted the same scope of assumedly intra-specific variation that he found in the type stratum (bed 40 of the Cellon section), for the vertical range of $\mathrm{Pa}$ elements that he observed in the relevant Cellon section and that he identified as "Spathognathodus st. eosteinhornensis" from the base of the Přídolí onward. In pelagic sections in Europe (outside of Baltica - where some different taxa lived) the occurrence of somewhat similar $\mathrm{Pa}$ elements (with small basal lobes near mid-length, without ornamentation on the lobes, but mostly fairly equidentate), was apt to suggest an "eosteinhornensis" Zone that comprised the entire Přídolí Series. As similar Pa elements are found even in the late Ludlow, it has been discussed whether the eosteinhornensis Zone begins that early (Cooper 1980, fig. 5). (The first co-occurrence to be discovered of genus $F$ crispus and an equidentate $\mathrm{Pa}$ element of such aspect was that by Bultynck \& Pelhate 1971, in the Armorican Massif. It concerned Zieglerodina? zellmeri sp. nov.)

Some authors stated that Pa elements like the holotype of the index are limited in the Cellon section to beds 40A and 41 (Klapper \& Murphy 1974, p. 42) or to beds 40 to 43B (Jeppsson 1974, p. 38; cf. Walliser 1964, pl. 20, figs 19-21). But even then, the downward extended range of the so-called eosteinhornensis Zone was not corrected and restricted.

The desire to distinguish the very late Silurian from the very early Devonian utilising the assumed phylogenetic step from "Spathognathodus steinhornensis eosteinhornenis" towards "Spathognathodus steinhornensis remscheidensis" has provoked several efforts to characterize the taxa "eosteinhornensis" and "remscheidensis" through distinctive features. Such enterprises have started from the premise that the dominant feature of "eosteinhornensis" is the rather equidentate denticulation of its blade, whereas "remscheidensis" has denticles of very different sizes. The distinction was complicated through the synonymization of "Spathognathodus" canadensis (Walliser, 1960) with Zieglerodina remscheidensis. [This problem is eliminated through the attribution of canadensis to the genus Lanea Murphy \& Valenzuela-Ríos, 1999, because of its broad and terraced basal lobes. Jeppsson (1974, p. 38) had already stated that its white matter is distributed in a manner reminding of Ozarkodina.] Additionally, several other late Silurian taxa have been identified as "remscheidensis" that, indeed, have denticles of different sizes, but do not have them arranged as in the type material (see Murphy et al. 2004, pp. 13, 14). Relevant studies in Nevada (Klapper \& Murphy 1974), in Estonia (Viira 1999, Jeppsson et al. 1994), in the Appalachian Basin (Barnett 1971, 1972), in the Barrandian area (Mehrtens \& Barnett 1976), and in Oklahoma (Barrick \& Klapper 1992) appeared that reported "eosteinhornensis". However, in these studies true genus W eosteinhornensis was not represented. Genus W eosteinhornensis has not been figured from Baltic localities. Viira \& Aldridge (1998, pl. 4, figs 10, 13-17) stated "Ozarkodina remscheidensis eosteinhornensis (Walliser, 1964) sensu lato", of which figs 13-15 are Zieglerodina? zellmeri, whereas the shorter and relatively higher and less evenly denticulated fig. 10 is a different taxon. Viira (1999, pl. 3, fig. 2) refigured the specimen of the former on fig. 13 as "Ozarkodina remscheidensis eosteinhornensis (Walliser)". Jeppsson et al. (1994, fig. 4h, i) figured the latter specimen and a less developed one as " 'O. remscheidensis - O. eosteinhornensis s.l. group' ". Jeppsson et al. (1994, fig. $4 \mathrm{j}-\mathrm{m}$ ) additionally figured shorter Pa elements with more acute denticles of slightly less even sizes as "same group as (h)", joining them in one taxon. Associated ramiform elements were not shown. Even Mehrtens \& Barnett (1976), who had their samples from the Požáry section in the Barrandian area, where characteristic eosteinhornensis is found, did not figure such specimens nor did they refer in the text to the particular morphology corresponding to the holotype. At Požáry, Pa elements with well ornamented basal lobes occur from about $17 \mathrm{~m}$ above the base of the Príidolí within about $2 \mathrm{~m}$ and, strikingly once again, about $5 \mathrm{~m}$ below the first Icriodus near the S/D boundary ( $c f$. Fig. 4).

For merely technical purposes, one may refer to an "eosteinhornensis group" of taxa that have been lumped with true eosteinhornensis in the type section at Cellon. As noted above, true eosteinhornensis is known at Cellon only in $2 \mathrm{~m}$ or $5.5 \mathrm{~m}$ of strata. Actually, the occurrence of the taxon eosteinhornensis s.s. corresponding to the characterization by Jeppsson (1974) and by Klapper \& Murphy (1974), has only been demonstrated in the following locations: type region Carnic Alps (Walliser 1964, pl. 20, figs 19, 21, 22); Barrandian (Jeppsson 1989, pl. 2, figs 1-4); borehole Chełm (Wolska 1969, stating presence of a node, basinal facies off the Baltic Platform) and Frankenwald (this paper). Accordingly, the current application of the eosteinhornensis Zone beyond these records is not well-founded. Its presence has been merely assumed on the basis of several clearly different taxa through a long time-interval, across the Ludlow/Príidolí boundary (e.g., Bultynck \& Pelhate 1971, pl. 1, figs 1-3, 21; Rexroad \& Craig 1971, pl. 82, figs 18, 10; Cooper 1980, fig. 5; Aldridge et al. 1979, p. 437, fig. 1, No. 102; Kleffner 1989, fig. 6, No. 10). 

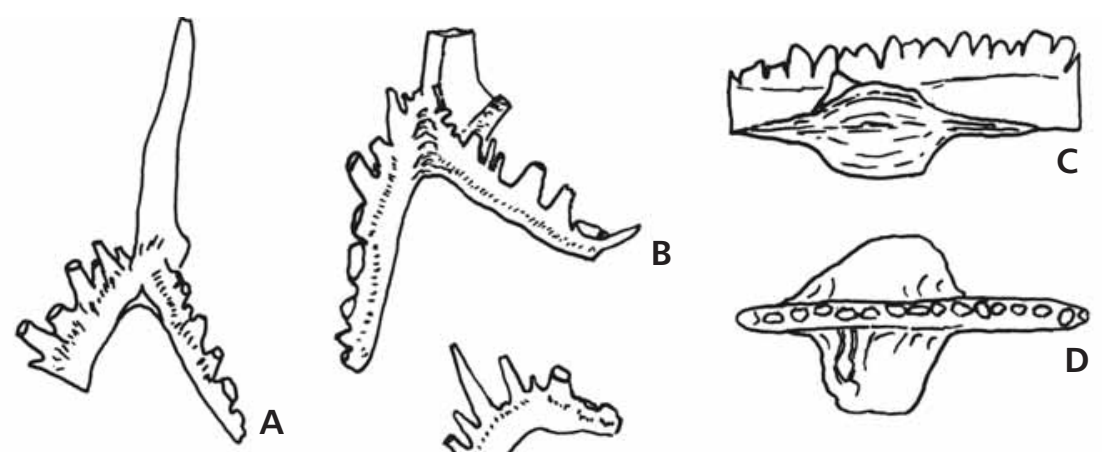

\section{,}
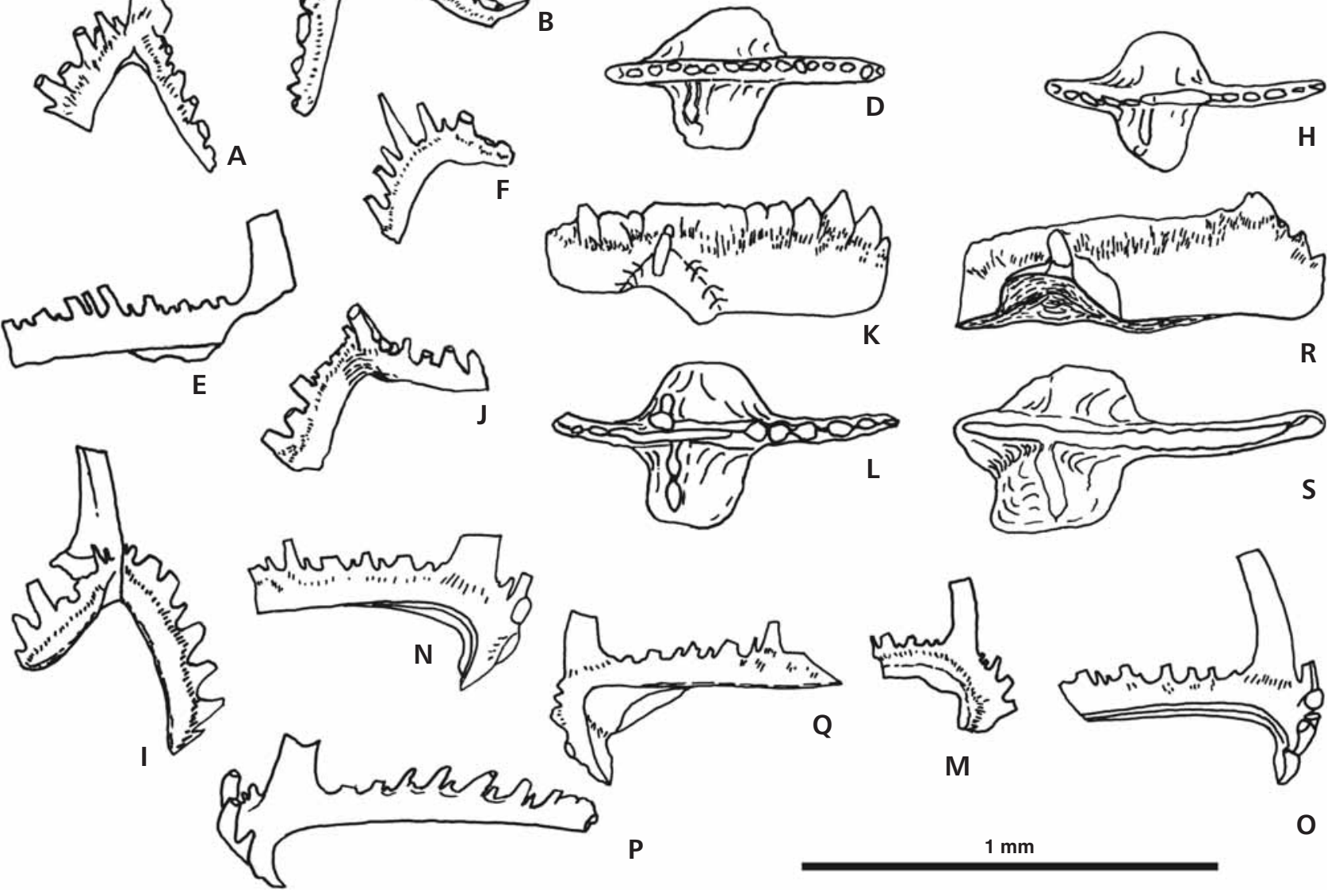

Figure 3. Camera lucida drawings of taxa: Delotaxis detorta, Delotaxis sp. and gen. W eosteinhornensis. $\bullet$ A - Delotaxis detorta, incomplete Sa, cat. No. L38675, Požáry section, sample PZ076, obliquely anterior view. • B - Delotaxis detorta, Sb element, cat. No. L38676, Požáry section, sample PZ078, inner upper view. $\bullet$ C, D - gen. W eosteinhornensis, Pa element, cat. No. SMF69987, EOL section, sample 5, C - outer lateral view, D - upper view. $\bullet$ E Delotaxis detorta, incomplete Sc element, cat. No. L38677, Požáry section, sample PZ076, same as Fig. 8K, lateral view. • F - Delotaxis detorta, incomplete Sb element, cat. No. L38680, Požáry section, sample PZ078, oblique inner view. • G, H - gen. W eosteinhornensis, Pa element, cat. No. SMF69988, EOL section, sample 5, G - outer lateral view, H - upper view. • I - Delotaxis sp., a strongly angular Sb element with a small denticle, cat. No. L38678, Požáry section, sample PZ076, inner lateral view, same as Fig. 8I, J. • J - Delotaxis detorta, Sb element, cat. No. L38681, Požáry section, sample PZ078, inner lateral view. $\bullet \mathrm{K}, \mathrm{L}$ - gen. W eosteinhornensis, Pa element, cat. No. L38682, Požáry section, sample PZ083, K - outer lateral view, L - upper view. • M - Delotaxis detorta, Sc element, cat. No. L38679, Požáry section, sample PZ076, same as Fig. 8L, outer lateral view. • N - Delotaxis detorta, Sc element, cat. No. SMF69972, erratic boulder, sample Lag Vas 4, outer lateral view. $\bullet$ O - Delotaxis detorta, Sc element, cat. No. SMF69973, erratic boulder, sample Lag Vas 4, inner lateral view. $\bullet \mathrm{P}-$ Delotaxis detorta, Sc element, cat. No. SMF69989, EOL section, sample 6, inner lateral view. $\bullet \mathrm{Q}-$ Delotaxis detorta, Sc element, cat. No. SMF69974, erratic boulder, sample Lag Vas 4, outer lateral view. $\bullet$ R, S - gen. W eosteinhornensis, Pa element, cat. No. L38683, Požáry section, sample PZ083, R - outer lateral view, S - upper view.

\section{The Silurian "remscheidensis interval Zone"}

Close to the Ludlow/Přídolí boundary, the steinhornensis plexus produced early members with increasingly uneven denticulation that were attributed to "Ozarkodina" remscheidensis. When a "remscheidensis interval Zone" was therefore proposed for most of the Přídolí, the name of a taxon that is actually a Devonian species, was introduced into Silurian biozonation (see Fig. 1). That would be con- fusing and is unacceptable. The main distinguishing criterion considered was the uniformity versus variation of denticle sizes in the Pa elements. Apparatus reconstructions were not taken into account. Under the concept of intra-specific evolution with interbreeding, no species were separated. But differences in non-Pa elements suggest even generic difference from Zieglerodina remscheidensis. Moreover, Zieglerodina remscheidensis s.s. is the successor of Zieglerodina sp. 40 (Carls 1975, pl. 2, 


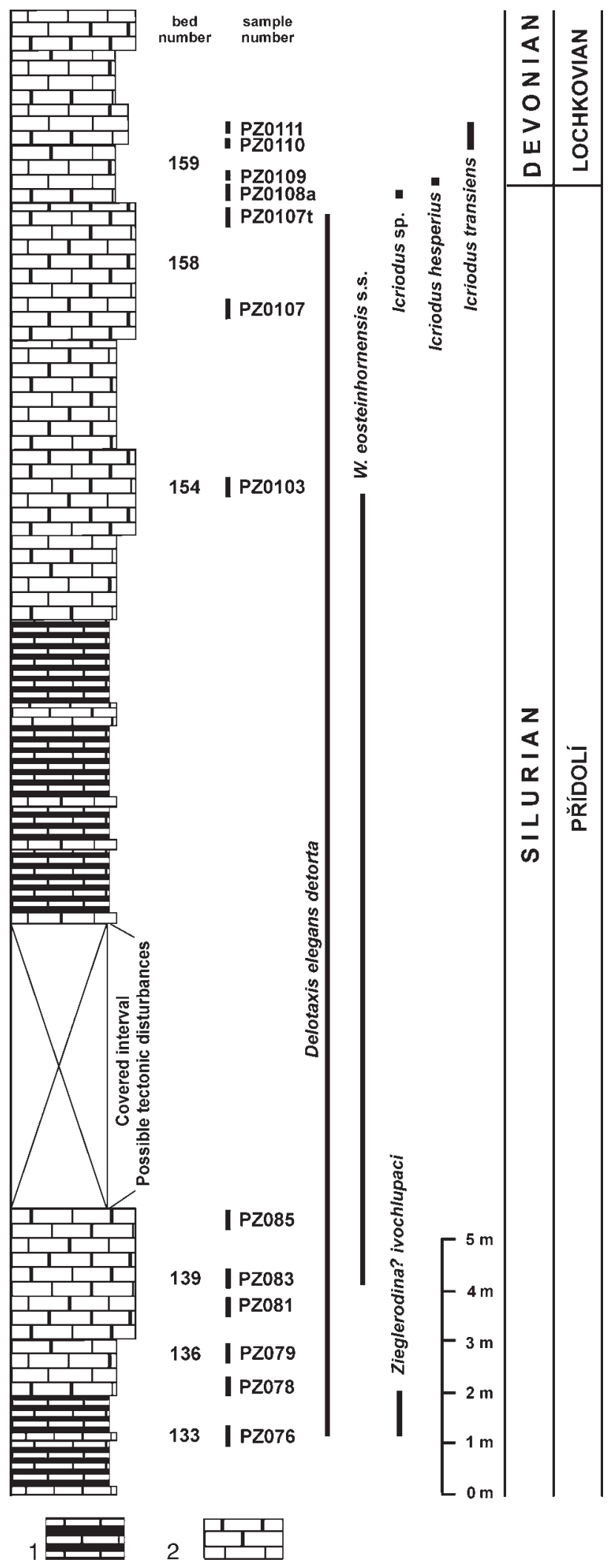

Figure 4. Požáry section. Stratigraphical distribution of relevant conodont taxa from the interval below the Silurian/Devonian boundary of the Požáry section. Lithology: 1 - calcareous shale, 2 - limestone beds, mostly grainstones and packstones. Bed numbering after Kř̌̌ž et al. (1986). figs 16-18) and enters as late as after the entries of the Devonian index fossils Acastella heberti, Platyorthis monnieri and Icriodus sp. ex gr. woschmidti that range in the uniformis Zone - i.e. well in Lochkovian time (Carls 1975). [The attribution of the type stratum of remscheidensis to the late Silurian by Jeppsson (1988), was an error - see below.]

\section{Discussion of the detorta Zone}

The intercalation of small denticles between large ones is, according to Jeppsson (1974, pp. 21, 22), diagnostic for the identification of the taxon Delotaxis elegans detorta (Walliser, 1964). In the conodont samples studied through the middle and late Přídolí up to the Lochkovian beds of the Požáry Quarries, there are elements of Delotaxis, virtually up to the end of the Silurian, with small denticles intercalated between the "normal" big ones. This feature has been observed previously in actually latest Silurian successions at other localities (Jeppsson 1974, p. $22 ; 1988 ; 1989)$.

In the standard sections at Cellon and Klonk, Delotaxis elegans detorta has only been reported above the range of gen. W eosteinhornensis and below the base of the Devonian. The multielement taxon $D$. detorta was designated by Jeppsson (1988, p. 25) as the index of the detorta Zone, the range of which was assumed to be only the latest Přídolí. This was based mainly on the Cellon section, which has, however, a remarkably low diversity in the early Přídolí.

It is possible that intercalation of small denticles in Delotaxis is not a phylogenetically distinctive but a general feature, but we have not investigated this. [It should be taken into account that there exist very frequent specimens, mainly Sc and Sa elements, of Delotaxis that have one to three thin and short denticles only immediately behind or anterior of the cusp but lack small denticles in more distal interspaces. The presence of small denticles only in these proximal positions is not considered relevant for a (sub)specific identification.]

When elements resembling Delotaxis elegans but with intercalated small denticles were found in samples from the East Baltic Beyrichien-Kalk (Jeppsson 1972, p. 56; 1974, p. 22), they were identified as Delotaxis elegans detorta and they were assumed to indicate the final Silurian conodont zone. However, in the Baltic successions (excepting the Chełm bore), there is no gen. W eosteinhornensis s.s., reference to which might enable to control the lower limit of the range of $D$. detorta. Moreover, the interval immediately below the Silurian-Devonian boundary cannot be demonstrated in the Baltic area by means of overlying relevant faunas, as such are lacking there. Thus, the Baltic ranges of $D$. detorta cannot be calibrated according to the 
same conodont criteria that have been applied in the Cellon and Klonk sections.

The development of alternating denticle sizes is not limited to the lineage elegans-detorta. Viira (1999, pl. 4, fig. 10) has figured an Sb? element as "Oulodus elegans detorta (Walliser)"; this specimen has single small denticles in at least four interspaces of its anterior branch, but it is probably not conspecific with $D$. elegans nor D. detorta, because similar specimens are absent from most samples that contain abundant and well balanced elements of Delotaxis elegans. However, similar elements, although generally without intercalated small denticles, are not too scarce in Nordic erratics of late Silurian age. One was figured by Walliser (1964, pl. 30, fig. 5, without stratigraphic information). In Nordic erratics they often occur with Delotaxis ex gr. salopia-silurica. Viira's specimen demonstrates that the appearance of small denticles represents a more widespread trend in Delotaxis and is not, per se, a reliable basis for the recognition of a conodont zone.

In material from the type section of the Přídolí, there are elements of Delotaxis with a few alternating denticles (Figs 3, 8) appearing $10 \mathrm{~m}$ below the entry of gen. W eosteinhornensis, and they range beyond the latter up to the end of the Silurian (Fig. 4). This means that a detorta Zone as a successive appearance zone with the index chosen by Jeppsson (1988) would not represent the uppermost Přídolí, but a relevant interval preceding the eosteinhornensis Zone s.s., whereas the interval between the appearances of genus W eosteinhornensis and Icriodus hesperius would be the eosteinhornensis Zone proper in the sense of successive appearance zonation.

As evidence of the wider occurrence of this succession, there is D. detorta in the Elbersreuth Orthoceratid Limestone in the Frankenwald below genus W eosteinhornensis (Fig. 5), whereby the observation from the Požáry section is corroborated. These results provoke doubts about the assumedly final Přídolí ages of uppermost Silurian horizons in the East Baltic and of the Beyrichien-Kalk, as far as they are dated by means of D. detorta.

\section{Additional evidence}

\section{Conodont data from the Elbersreuth Orthoceratid Limestone}

A succession of conodont samples from the Elbersreuth Orthoceratid Limestone (= EOL) on the Schübelebene of the Frankenwald (NE Bavaria) has been studied in order to test the above results. This section also furnishes some evidence for correlation with Baltica.

This small abandoned quarry with late Silurian to Late

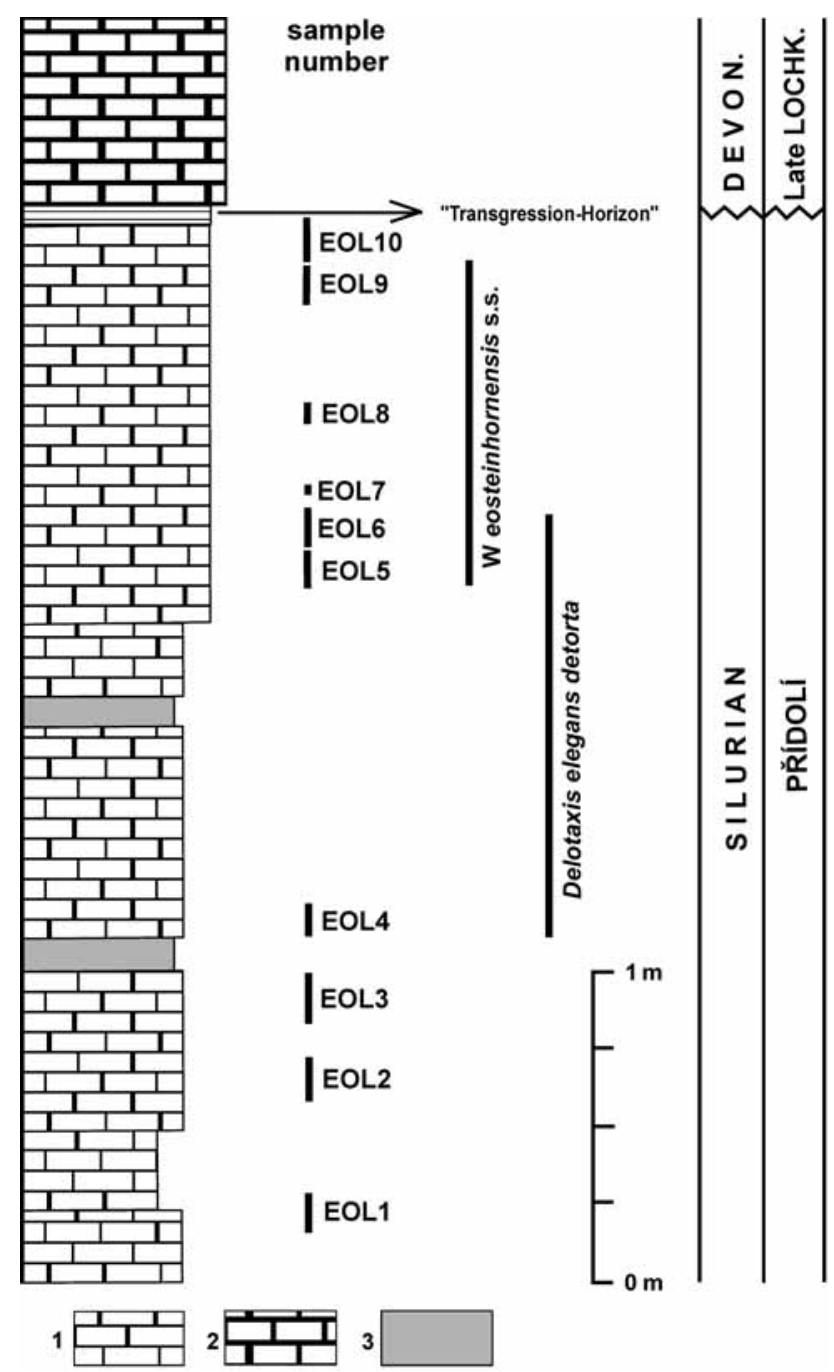

Figure 5. Elbersreuth section. Stratigraphical distribution of relevant conodont taxa from the interval below the Silurian/Devonian boundary of the Elbersreuth Orthoceratid Limestone (Frankenwald). Lithology: 1 thin-bedded to well-bedded cephalopod grainstones, 2 - massive Lochkovian cephalopod grainstones with dacryoconarids, 3 - laminated karst fillings of Lochkovian age.

Devonian conodont record is the locality of the famous Transgression Horizon, from which Bischoff \& Sannemann (1958) obtained their condensed Lochkovian fauna with Pedavis pesavis. This condensed level is underlain unconformably by the EOL. Together with J. Gandl and D. Al-Rawi, P. Carls sampled the EOL in 1968. The measured section is shown in Fig. 5. The present section base is $3.30 \mathrm{~m}$ below the Transgression-Horizon. There are two different horizontal Lochkovian karst fillings parallel to the bedding that are $6 \mathrm{~cm}$ and $7 \mathrm{~cm}$ thick; their conodonts are not considered herein. The lowermost beds of the EOL are reported to bear Kockelella variabilis (Walliser, 1957). The EOL conodonts contribute to the correlation with Baltic successions. 


\section{Comments on conodont faunas from some samples shown on Table 1}

Sample EOL 1 (13 cm to $30 \mathrm{~cm}$ above the section base) This fauna is as old as or, possibly, younger than the level at which alternating denticle sizes in the ramiform elements of Spathognathodontidae (?Zieglerodina sp.) appear and Delotaxis of the elegans stock enters. In the upper Ludfordian of Gotland these features are observed in the middle of member b of the Hamra Fm. (Jeppsson et al. 1994, fig. 3).

Sample EOL 3 (80 cm to $100 \mathrm{~cm}$ above the section base)The presence of one specimen of Icriodus results from admixture of Devonian conodonts in a palaeokarst fissure; the single Pa element of gen. W eosteinhornensis may have the same provenance. In any case, it would occur before the acme of this index.

Sample EOL $4(106 \mathrm{~cm}$ to $120 \mathrm{~cm}$ above section base above the lower karst filling) - No conodont present might be attributed to the "eosteinhornensis group". Wurmiella reclinata is known from the Grebenski "Horizon" of the Vaigatch Peninsula that has been correlated with the Kaugatuma "Stage" of Estonia. The Sb element figured by Viira (1999, pl. 4, fig. 10) as "Oulodus elegans detorta (Walliser)" from the upper part of the Ohesaare "Stage", with small denticles in several interspaces of its anterior branch, is matched here by one similar Sb element of $D$. silurica-salopia that has one small denticle just in front of the cusp and one between the first and second big posterior denticles. Sc elements of $D$. detorta have a few intercalated small denticles on the posterior branch. This sample belongs in the range Kaugatuma-Ohesaare and below the acme of gen. W eosteinhornensis s.s. At low accumulation rate, more than $80 \mathrm{~cm}$ below the acme of gen. W eosteinhornensis, the sample proves the entry of alternating denticulation in two Delotaxis stocks.

Sample EOL 5 (2.11 to 2.27 m above the section base) This is the first sample with hundreds of $\mathrm{Pa}$ elements of gen. W eosteinhornensis s.s. They have the large basal cavity in a rather posterior position, mostly with a node on the outer lobe, and many have the median denticles of the blade fused; within the underlying $65 \mathrm{~cm}$ (not sampled beds) the acme of this taxon might still be extensible.

The Wurmiella $\mathrm{Pa}$ elements have about 10 anterior denticles, the cusp, and 4-5 posterior ones, which may provide an additional mark.

The specimens of the Pa element of Amydrotaxis? cf. praecox are smaller than the one figured by Viira (1999, pl. 4, fig. 11; 2000, pl. 4, fig. 1). The taxon was reported from the eastern Baltic, above local finds of the Delotaxis detorta plexus, and it was considered to be just below the
Silurian-Devonian boundary. But in the EOL A. cf. praecox is of mid-Přídolí age.

Sample EOL 6 (2.28 to $2.45 m$ above section base) - In Nevada, Klapper \& Murphy (1974) have found the delta morphotype of $\mathrm{Oz}$. typica within the upper range of Pelekysgnathus index, i.e. between the crispa Zone and the end of the Přídolí; the specimens figured by Walliser (1964, pl. 22, figs 16,18 - only) are from near the bed 39A of the Cellon section, i.e. virtually at the entry of gen. W eosteinhornensis. From the evidence in Nevada, at the Cellon, and at Elbersreuth a range of the delta morphotype from near the middle of the Přídolí into its last quarter can be established. The presence of one Sc element of D. detorta with one small denticle in each interspace on the bar confirms that the full degree of alternation is reached within the eosteinhornensis acme. One Pa element of Coryssognathus $d u-$ bius provides evidence for the presence of the species.

Sample EOL 7 (2.40 $m$ to $2.45 m$ above section base) Most gen. W eosteinhornensis have a node on the outer basal lobe, but welding of denticles does not occur. Two Sc elements of $D$. detorta have one small denticle in each interspace.

Sample EOL 8 (2.65 $m$ to $2.75 m$ above section base) - The acme of gen. W eosteinhornensis has ended, 2 of its Pa elements have nodes, but no fusion of denticles; the Pa elements of Wurmiella reach over 20 denticles.

Sample EOL 9 (3.02 $m$ to $3.20 m$ above section base) - The Pa specimens of Wurmiella excavata are small, short, but high. There is only one small Pa element of gen. W eosteinhornensis with a small node. Oz. nasuta is in upper Kaugatuma and Ohesaare Fm. of Estonia (Viira 1983).

Sample EOL 10 (3.20 to $3.32 \mathrm{~m}$ above section base) - Gen. $\mathrm{W}$ eosteinhornensis has not been found and is either very scarce or extinct. Thus, this sample corresponds to somewhere in the late Přídolí part of the Klonk section, from bed 12 onward, because gen. W eosteinhornensis ends below bed 12 (Jeppsson 1988, tab. 1). At Klonk, gen. W eosteinhornensis overlaps with "Ozarkodina s. remscheidensis sensu nov." of Jeppsson (1989, pl. 2, figs 6-11) (= Zieglerodina? klonkensis sp. nov.). This taxon is missing in the EOL.

The deposition of the EOL was interrupted close to the Silurian-Devonian boundary and karstification occurred. Within the Early Lochkovian, further conodont faunas were deposited; they begin with Icriodus woschmidti in the lower karst filling shown in Fig. 5.

If the scarce occurrences of Amydrotaxis? praecox and of $\mathrm{Oz}$. nasuta in Baltica and in the EOL are considered together, it appears that the eosteinhornensis s.s. acme was 
Table 1. Distribution of conodont taxa in samples from the Elbersreuth Orthoceratid Limestone (Frankenwald). Abreviations: X - present, XX - very frequent, a - some Sb with sharp angle, ? - presence uncertain, $\mathrm{O}$ - present, but probably karst reworked

\begin{tabular}{|c|c|c|c|c|c|c|c|c|c|c|}
\hline Sample / Taxon & 1 & 2 & 3 & 4 & 5 & 6 & 7 & 8 & 9 & 10 \\
\hline Sample weight $(\mathrm{kg})$ & 6.0 & 4.2 & 3.8 & 2.2 & 3.0 & 2.3 & 1.0 & 3.6 & 2.0 & 1.4 \\
\hline Coryssognathus dubius & & & & & & $\mathrm{X}$ & & & & \\
\hline Coryssognathus sp. & & $\mathrm{X}$ & & $\mathrm{X}$ & $\mathrm{X}$ & & & & $\mathrm{X}$ & \\
\hline Delotaxis elegans & $\mathrm{Xa}$ & $\mathrm{Xa}$ & $\mathrm{X}$ & $\mathrm{Xa}$ & & & $\mathrm{Xa}$ & & & $\mathrm{X}$ \\
\hline Delotaxis detorta & & & & $\mathrm{X}$ & $\mathrm{X}$ & $\mathrm{X}$ & $\mathrm{X}$ & & & \\
\hline Delotaxis sp. ex gr. salopia-silurica & $X$ & $\mathrm{X}$ & $\mathrm{X}$ & $\mathrm{X}$ & $\mathrm{X}$ & $X$ & & & $\mathrm{X}$ & $X$ \\
\hline Wurmiella excavata & $\mathrm{X}$ & $\mathrm{X}$ & $\mathrm{X}$ & & $\mathrm{X}$ & $\mathrm{X}$ & $\mathrm{X}$ & $\mathrm{X}$ & $\mathrm{X}$ & $\mathrm{X}$ \\
\hline Wurmiella? reclinata & & & & $\mathrm{X}$ & & & & & & \\
\hline Ozarkodina typica delta morph & & & & & & $\mathrm{X}$ & & & $\mathrm{X}$ & $\mathrm{X}$ \\
\hline Ozarkodina nasuta & & & & & & & & & $\mathrm{X}$ & \\
\hline W eosteinhornensis s.s. & & & $\mathrm{O}$ & & $\mathrm{XX}$ & $\mathrm{XX}$ & $\mathrm{X}$ & $\mathrm{X}$ & $\mathrm{X}$ & \\
\hline ?Zieglerodina sp. sp. & $\mathrm{X}$ & & $\mathrm{X}$ & & $?$ & & $\mathrm{X}$ & $\mathrm{X}$ & $\mathrm{X}$ & $\mathrm{X}$ \\
\hline Amydrotaxis? cf. praecox & & & & & $\mathrm{X}$ & & & & & \\
\hline
\end{tabular}

near the Ohesaare Stage. Accordingly, D. detorta in the Ohesaare corresponds only to the early part of its range in the Požáry section.

\section{The range of Delotaxis detorta in the Eastern Baltic}

Jeppsson (1988, p. 25) reported Delotaxis detorta from the Beyrichien-Kalk with the ostracods Nodibeyrichia gedanensis and Kloedenia wilkensiana, i.e. from the top of the stratigraphic succession of Gotland. Viira (2000) found it in the East Baltic region in the Ohesaare Stage; occasionally, it is associated with Ozarkodina nasuta (Viira, 1983) and it may be followed by Amydrotaxis? praecox Viira 2000, which is quite scarce and is also still within the range of O. nasuta. Viira (2000, p. 53) stated rightfully that the detorta range does not reach the base of the Devonian in the Baltic.

In the EOL, we have found comparable data: Delotaxis detorta enters before Amydrotaxis? cf. praecox (see Table 1), and O. nasuta is still found above both. The Baltic setting cannot be calibrated directly with the range of gen. $\mathrm{W}$ eosteinhornensis, because on the entire Baltic Platform this taxon has only been erroneously identified (no specimen with a node on the basal lobe has been found); however Wolska (1969, p. 586) mentioned it from the Chełm borehole in the basinal deposits, which means that it could reach the margin of Baltica. It did not occur on the platform either because the biofacies was inappropriate or because at its time the late Silurian regression had begun. The associations in the Požáry section and in the EOL prove that: 1. the index of the detorta Zone appears before the index of the eosteinhornensis Zone (see Figs 4, 5), 2. the ranges of the latter and of Amydrotaxis? praecox overlap, and 3. $O$. nasuta, which is unknown in the Devonian, reaches the end of gen. W eosteinhornensis.

Collating Jeppsson's observations of D. detorta from the latest Silurian of the Cellon and from the Klonk sections (Jeppsson 1988, p. 25) and the youngest findings from the Požáry versus the East Baltic ones, it appears that in the East Baltic only the lower part of the range of $D$. detorta has been observed, and that begins before gen. $\mathrm{W}$ eosteinhornensis. It is not warranted that the Baltic conodont faunas survived the eosteinhornensis acme, but their earlier end cannot be excluded.

\section{Some Spathognathodontidae of the late Silurian}

Within the Spathognathodontidae of the late Silurian, the technical steinhornensis plexus comprises the apparatuses with alternating denticulation of ramiform elements. Three groups of them can easily be distinguished within this plexus:

A) $\mathrm{Pa}$ elements with a large, broad and asymmetrical basal cavity in a rather posterior position and with rather equidentate denticulation of the blade. This kind corresponds to gen. W eosteinhornensis; it can be subdivided according to two criteria that vary independently: a) A node at least on the outer lobe or without a node. b) Some denticles near the cusp are fused or all have free tips. The holotype of the taxon eosteinhornensis has a node and its denticles are not fused. The most characteristic specimens are those with both node and fusion. The fusion increases with maturity. Murphy et al. (2004, p. 15, 16) defined corresponding morphotypes.

B) Pa elements with the centre of their smooth basal cavity close to mid-length, with a fairly symmetrical 
"bell-like" (sensu Jeppsson 1974, p. 39) outline of the basal cavity, and with rather equal heights of their denticles. Their equidentate condition was the reason for their original inclusion in the taxon eosteinhornensis, but their basal lobes distinguish them. Nevertheless, they were technically joined in the informal eosteinhornensis group for provisional classification. This group consists of a number of independent taxa that still await evaluation.

C) Pa elements with their basal lobes as in group B, but with markedly unequal sizes of their denticles. Some of these $\mathrm{Pa}$ elements are joined to ramiforms that are close to those of the multi-element genus Zieglerodina Murphy et al. 2004. Corresponding elements figured from the type stratum of Zieglerodina remscheidensis (Ziegler, 1960) are helpful guides for the separation. Where apparatus reconstruction was not yet possible, the Pa elements with uneven denticulation were joined in the collective remscheidensis group.

Additionally, there are late Silurian taxa with incipient or developed alternation in their ramiform elements that do not fit in the groups A-C; e.g., Zieglerodina? klonkensis sp. nov. and Parazieglerodina plodowski Carls, Slavík \& Valenzuela-Ríos, 2005 both with transversely extended basal cavities.

In Cellon bed 40 the groups A, B and C are present and were originally attributed to the taxon eosteinhornensis. Therefore the identification of quite various $\mathrm{Pa}$ elements from other beds of the Cellon section and other sources under this name is easy to understand. Due to local conditions of partly low conodont diversities in the Cellon collections from the latialatus Zone onwards, the local entries of Pa elements of group B are, in this historically important section, as late as in the initial Prrídolí. This is rather delayed, if compared to samples with Zieglerodina? zellmeri sp. nov. and additional "Oz." crispa in the present erratic boulder L1 from Baltica and in western Armorica (Bultynck \& Pelhate 1971) that can be correlated from the late Ludfordian onwards. Authors who would include such fairly equidentate $\mathrm{Pa}$ elements in the taxon eosteinhornensis, would have to begin the eosteinhornensis Zone amid the Ludfordian. This was, indeed, practised by Kleffner (1989, fig. 6).

In erratic sample L1 with Zieglerodina? zellmeri sp. nov. there were also $7 \mathrm{~Pa}$ elements of the alpha 2 morph of "Ozarkodina" crispa (Walliser, 1964) sensu Viira \& Aldridge, 1998 (see Fig. 6H, I); additionally, there are abundant Delotaxis elegans of large and robust growth; this taxon is reported by Jeppsson et al. (1994, fig. 3) to be frequent in the East Baltic from the beginning of the Přídolí onward.

The specimens of "Ozarkodina" crispa alpha 2 morph sensu Viira \& Aldridge (1998, pl. 2, figs 1, 2; pl. 3, fig. 11) are identical to those from the Estonian Sauvere Beds where this taxon enters; but the "alpha 2 morph" is addi- tionally reported up to the top of the Kuressaare Regional Stage (the Kudjape Beds) from the Kolka borehole by Viira \& Aldridge (1998), which is considered as late Ludlow (latest Ludfordian).

Combining the age criteria of the full development of D. elegans, of the good development of alternating denticulation in Z.? zellmeri, the reports of the Pa element of the latter from Estonia, and the upper range of the " $O z$. ." crispa alpha 2 morph, our erratic sample L1 should be assigned to immediately below the Ludlow/Přídolí boundary. The apparatus of Z.? zellmeri is also found at the Požáry section in the basal bed of the Prrídolí, and we reject the references that have been made repeatedly by means of it to gen. W eosteinhornensis. Reports of gen. W eosteinhornensis from strata of Ludfordian and early Přídolí age must generally be doubted.

\section{Framework of late Silurian conodont succession in the Požáry section and some correlations}

The conodont succession of the late Ludlow and Přídolí at Požáry is under study. At present, the following levels important for conodont biostratigraphy can be reported:

$9.2 \mathrm{~m}$ below the Ludlow/Přídolí GSSP boundary there is Parazieglerodina plodowskii Carls et al., 2005 with initial development of alternating denticulation in its ramiforms, co-occurring with Pedavis latialatus (Walliser, 1964).

8.2 m below the series boundary "Oz." snajdri enters. The transition from the latter to "Oz." crispa occurs $7.0 \mathrm{~m}$ below the boundary.

The last Ped. latialatus occurs $3.2 \mathrm{~m}$ below the boundary and is accompanied by Ozarkodina cornidentata (Viira, 1983), and $3.0 \mathrm{~m}$ below the boundary Ozarkodina ambiqua (Viira, 1983) occurs. In the East Baltic Ohesaare borehole, the former is released by the latter near the passage between the regional stages K2 and K3.

"Ozarkodina" crispa is very abundant $1.80 \mathrm{~m}$ below the Ludlow/Přídolí boundary.

In the basal bed of the Přídoli there is Zieglerodina? zellmeri. Ozarkodina typica (= Spathognathodus primus = Ozarkodina confluens auctorum) occurs $20 \mathrm{~cm}$ above the base of the Přídolí; these specimens are comparable to Viira's (2000, pl. 2, fig. 8) find from the stage K4.

$7.0 \mathrm{~m}$ above the boundary the first Delotaxis elegans has single small denticles only next to the cusp (this incipient stage of alternation does not prove $D$. detorta: there must be additional small denticles intercalated along a branch.

$14.5 \mathrm{~m}$ above the boundary the first Delotaxis detorta with several intercalated small denticles and Zieglerodina? ivochlupaci sp. nov. occur (see Figs 3, 4). Both 

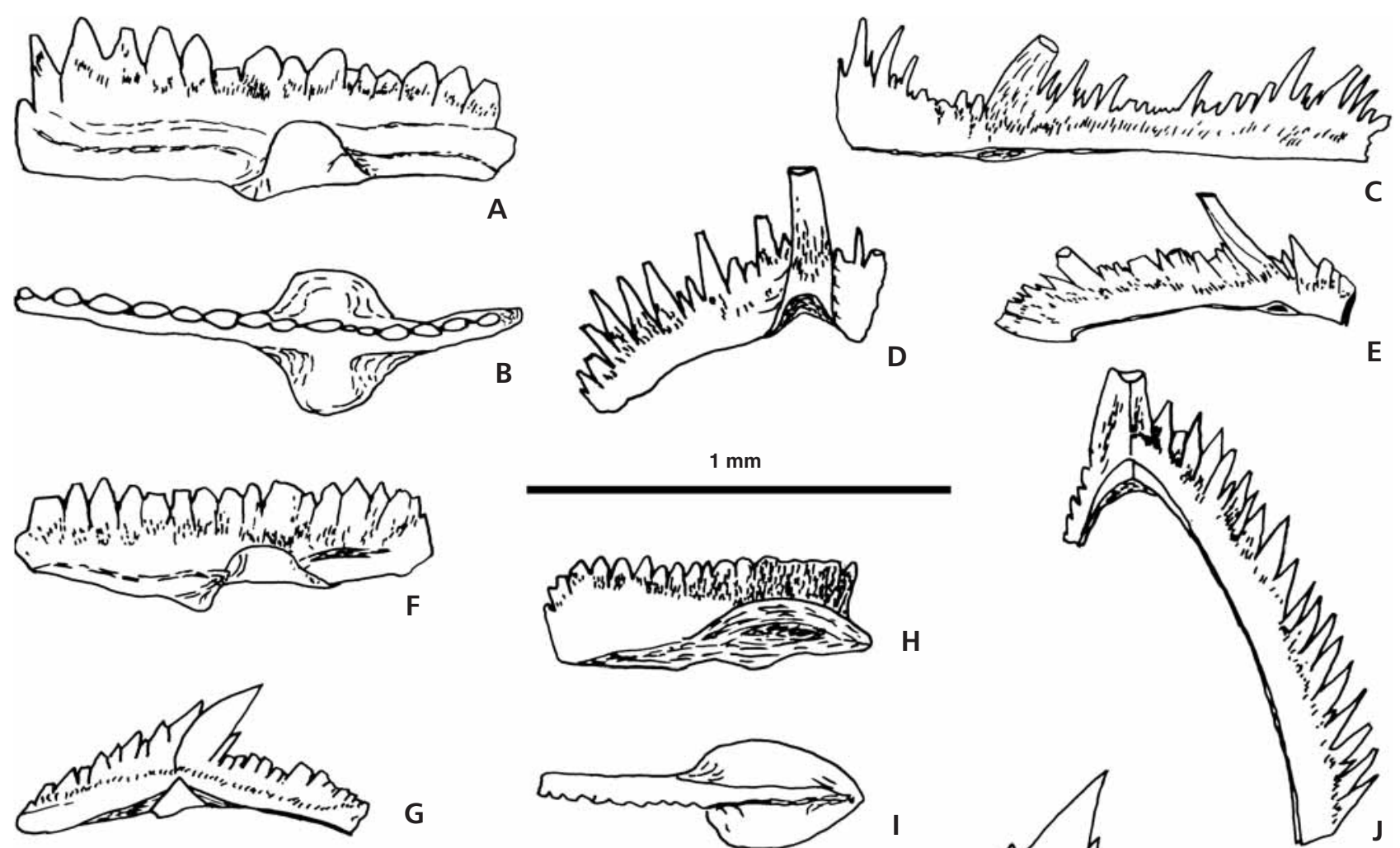

G
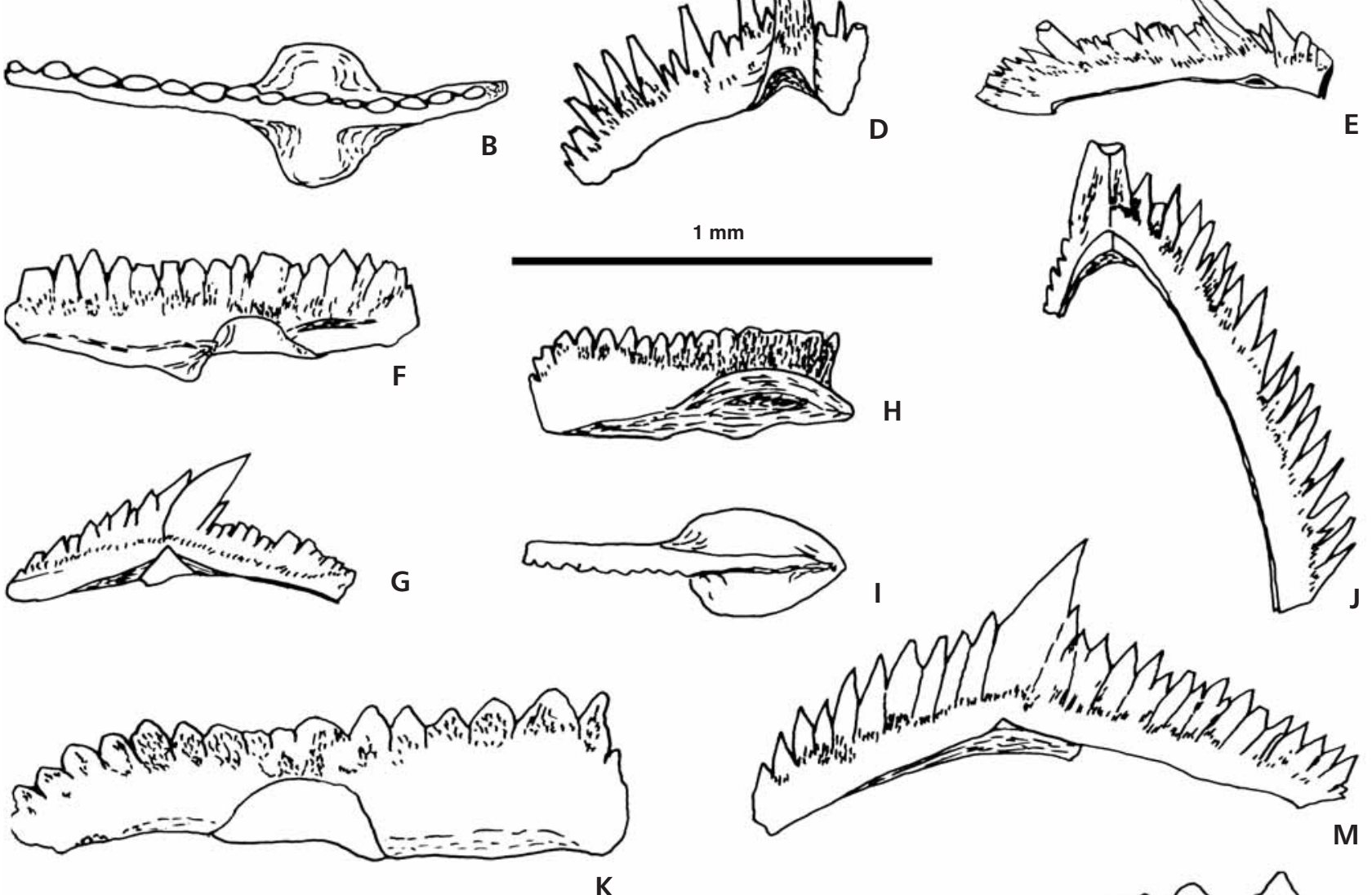

$E$

K
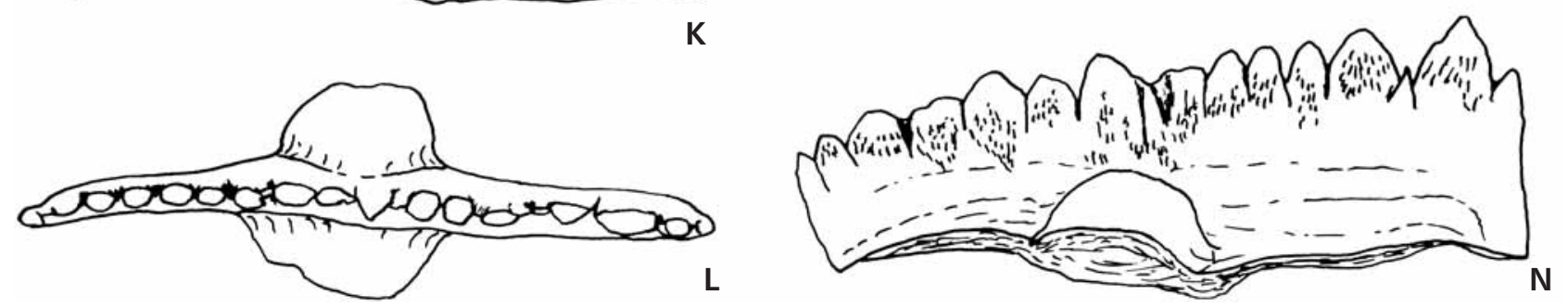

Figure 6. Camera lucida drawings - Zieglerodina? zellmeri sp. nov. (A-G, J-N). A, B - Pa element (holotype), cat. No. L38684, Požáry section, sample PZ030, A - inner lateral view, B - upper view. $\bullet$ C - Sc element, cat. No. SMF69980, erratic boulder, sample L1, inner lateral view. $\bullet$ D - incomplete Sa element, cat. No. SMF69981, erratic boulder, sample L1, posterior view. $\bullet$ E - Sb element, cat. No. SMF69982, erratic boulder, sample L1, inner lateral view. F - Pa element (paratype), cat. No. L38685, Požáry section, sample PZ030, inner lateral view. • G - Pb element, cat. No. L38686, Požáry section, sample PZ030, same as Fig. 8P, inner lateral view. • J - M element, cat. No. SMF69983, erratic boulder, sample L1, inner lateral view. $\bullet$, L - Pa element, cat. No. SMF69984, erratic boulder, sample L1, K - inner lateral view, L - upper view. $\bullet$ M - Pb element, cat. No. SMF69985, erratic boulder, sample L1, inner lateral view. $\bullet \mathrm{N}$ - Pa element, cat. No. SMF69986, erratic boulder, sample L1, inner lateral view. "Ozarkodina" crispa. • H, I - Pa element (lost), erratic boulder, sample L1, H - lower lateral view, I - upper view.

taxa also co-occur about half a meter higher (sample PZ078, see Fig. 4). This association also exists in Baltic erratic Lag Vas 4 proving an early range of the $D$. detorta in Baltica.

At Požáry, $17.7 \mathrm{~m}$ above the boundary gen. W eosteinhornensis s.s. enters; it abounds in about $1.5 \mathrm{~m}$; then follow almost $17 \mathrm{~m}$ without record of it. A last sample with gen. W eosteinhornensis s.s. (without welding of denticles) is $5.3 \mathrm{~m}$ below the first specimen of Icriodus.

$27 \mathrm{~m}$ above the GSSP, Zieglerodina? klonkensis sp. nov. enters; it is known through about $13 \mathrm{~m}$ up to $3 \mathrm{~m}$ below the Silurian/Devonian boundary. 
The youngest record of $D$. detorta is $20 \mathrm{~cm}$ below the first Icriodus sp.

$20 \mathrm{~cm}$ above the Icriodus sp., Icriodus hesperius Klapper \& Murphy, 1974 enters. $1 \mathrm{~m}$ above the latter mark I. aff. transiens Carls \& Gandl, 1969 corresponds to the earliest Lochkovian radiation of its genus. Previously, the entry of Warburgella of the rugosa group has been used as an approximation to the Silurian/Devonian boundary, about $2.5 \mathrm{~m}$ above the entry of Icriodus hesperius.

\section{Collation of late Silurian conodont distribution in the sections of Požáry and Elbersreuth and in the eastern Baltic}

The correlation of the conodont successions at Elbersreuth and in the Požáry section is most reliably based on the rich samples (acme) of gen. W eosteinhornensis observed at both localities. Additionally, the entry of Delotaxis detorta occurs, at both localities, shortly before the appearance of gen. W eosteinhornensis ( $c f$. Figs 4, 5). Accordingly, D. detorta in the Baltic localities, may be supposed to appear as early. As the Nordic erratic Lag Vas 4 contains the same association of the D. detorta and Zieglerodina? ivochlupaci sp. nov. as appears in the Požáry section, the regional entry of $D$. detorta in the Baltic in the early Přídolí is corroborated. That the youngest Baltic conodont faunas are in the early half of the Prídolí, it accords with the absence of true gen. W eosteinhornensis from that region. However, one can alternatively argue that this index is either too young to be present in that region before the late Silurian regression, or that it is withhold through the shallow facies. The latter version can be suggested through the preference this taxon has for deeper waters and it would forbid to draw conclusions on the age from the absence in shallow facies. Additional criteria are available: In the Baltic successions, Amydrotaxis? praecox follows the entry of D. detorta (Viira 2000, p. 4); at Elbersreuth, there is one record (cf.) together with rather early $D$. detorta and at the entry of gen. W eosteinhornensis. This points to the following succession of entries in the course of time and irrespective of the regions: 1. Zieglerodina? zellmeri sp. nov. during fading of the crispa plexus; 2 . the $D$. detorta and Zieglerodina? ivochlupaci sp. nov.; 3. Amydrotaxis? praecox; 4. gen. W eosteinhornensis; 5. Zieglerodina? klonkensis sp. nov.; 6. Icriodus sp. sp. The presence of Ozarkodina nasuta and other Ozarkodina s.s. seem to be more sporadic in pelagic facies than in the shallow Baltic waters and contribute only occasionally to the correlation. The Baltic spathognathodontan Pa element that has been most frequently figured under the name of "eosteinhornensis" is Zieglerodina? zellmeri sp. nov., that overlaps with "Oz." crispa. According to experience with the taxa crispa and eosteinhornensis s.s., in pelagic facies, there is a long interval between both that comprises the early third or half of the Př́dolí. The late part of this separating interval has the $D$. detorta still without the index eosteinhornensis. Only this interval could be called the "detorta Zone", within the early Přídolí, but we do not recommend the use of this fact for formal zonation purposes, although the early entries of $D$. detorta are relevant for correlations. Formalizing the zonation does not really enhance the correlation, and the move of the zonal name from the end of the Prídolí to below its middle would be confusing.

\section{Conodonts above the Silurian-Devonian boundary (the "woschmidti Zone")}

The woschmidti Zone is considered and widely used as the earliest Devonian conodont Zone. It was already installed when all earliest Lochkovian Icriodus s.l. were still attributed to I. wo. woschmidti. However, by and by, it turns out that there was an early radiation of the woschmidti group, after which typical I. woschmidti Ziegler, 1960 have a rather late appearance and a marginal taxonomic position (compare irrespective of original identifications: Carls 1975, pl. 2, fig. 21; Uyeno 1981, pl. 5, figs 32, 33, also present in bed 159 of the Požáry section; none strictly identical with I. woschmidti s.s.). The named taxon with wide distri-

Figure 7. Camera lucida drawings of Zieglerodina? ivochlupaci sp. nov. • A, B - Pa element (holotype), cat. No. L38687, Požáry section, sample PZ076, A - upper view, B - lateral view. • C, D - Pa element (paratype), cat. No. L38689, Požáry section, sample PZ076, C - lateral view, D - upper view. •E - Pb element, cat. No. L38692, Požáry section, sample PZ076, inner lateral view. • F - M element, cat. No. L38693, Požáry section, sample PZ076, inner lateral view. • G, H - Pa element (paratype), cat. No. L38688, Požáry section, sample PZ076, G - upper view, H - outer lateral view. • I - Sc element, cat. No. L38690, Požáry section, sample PZ076, inner lateral view. • J - Sa element, cat. No. L38694, Požáry section, sample PZ076, posterior view. • K Sb element, cat. No. L38691, Požáry section, sample PZ076, inner lateral view. • L - Pa element, cat. No. SMF69975, erratic boulder, sample Lag Vas 4, lateral view. •M - Pa element (paratype), cat. No. L38695, Požáry section, sample PZ076, lateral view. • N - Pa element, cat. No. L38698, Požáry section, sample PZ078, lateral view. • O - Pa element, cat. No. SMF69976, erratic boulder, sample Lag Vas 4, lateral view. • P, T - Pa element (paratype), cat. No. L38696, Požáry section, sample PZ076, P - upper view, T - lateral view. • Q, R - Pa element, cat. No. L38699, Požáry section, sample PZ078, Q - lateral view, R - upper view. $\bullet$ S - Pa element, cat. No. SMF69977, erratic boulder, sample Lag Vas 4, lateral view. •U - Pa element (paratype), cat. No. L38697, Požáry section, sample PZ076, lateral view. •V, X - Pa element, cat. No. L38700, Požáry section, sample PZ078, V - upper view, X - lateral view. • W Pa element, cat. No. SMF69978, erratic boulder, sample Lag Vas 4, lateral view. • Y - Pa element, cat. No. SMF69979, erratic boulder, sample Lag Vas 4, lateral view. 

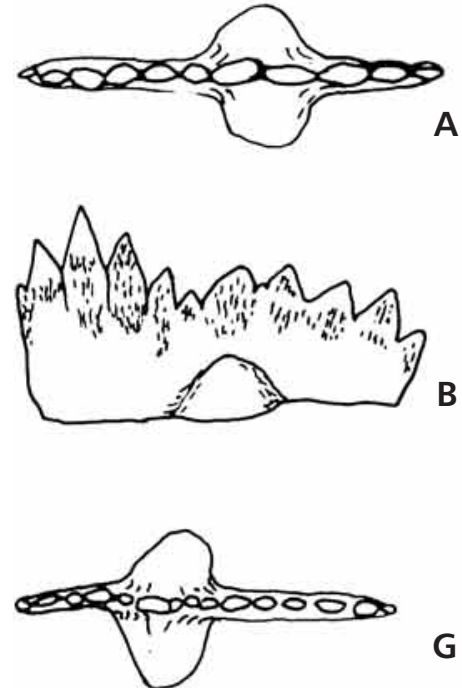

G
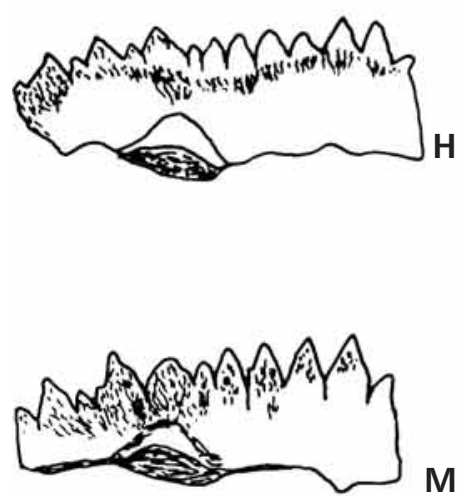

M
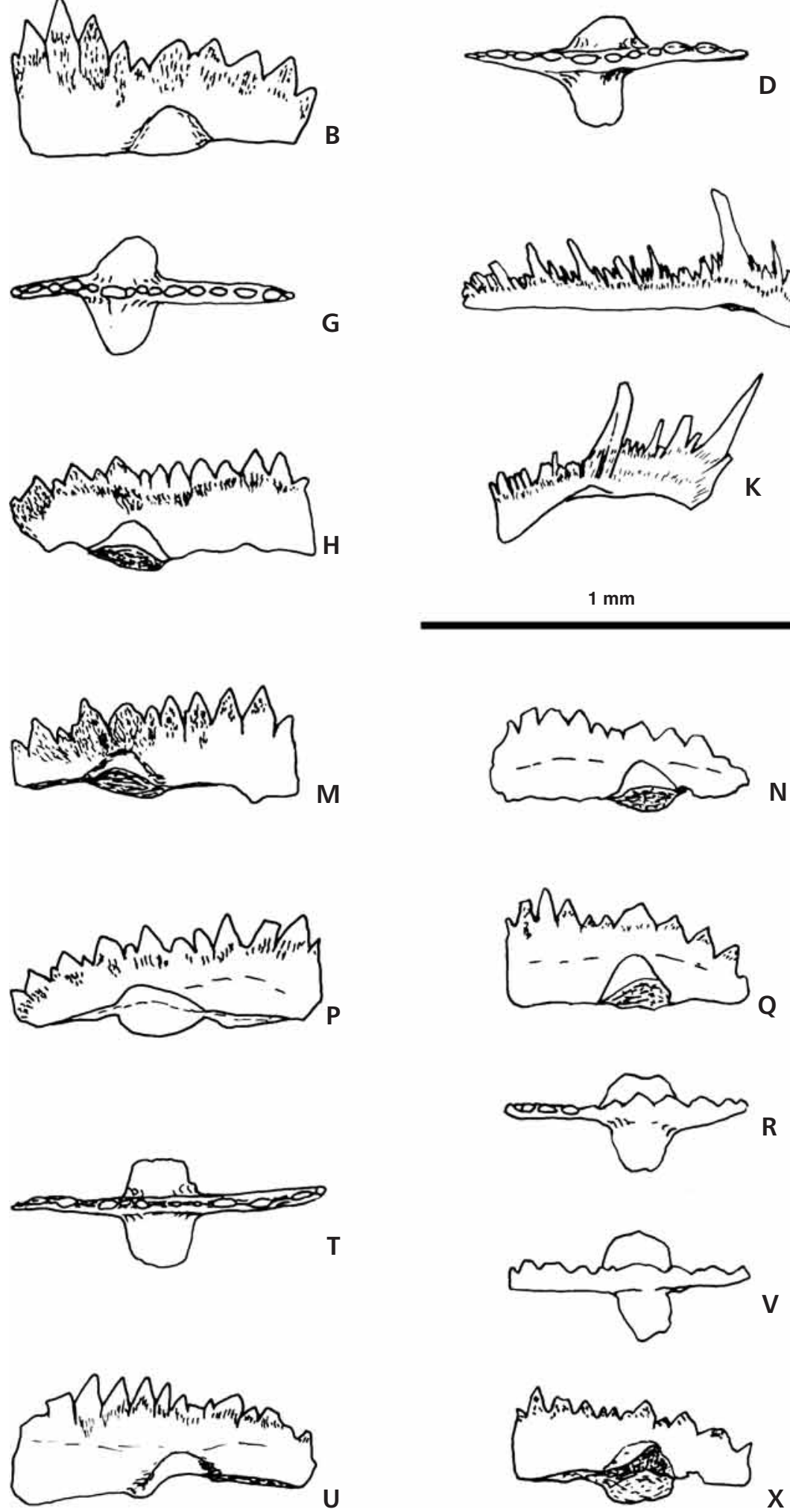
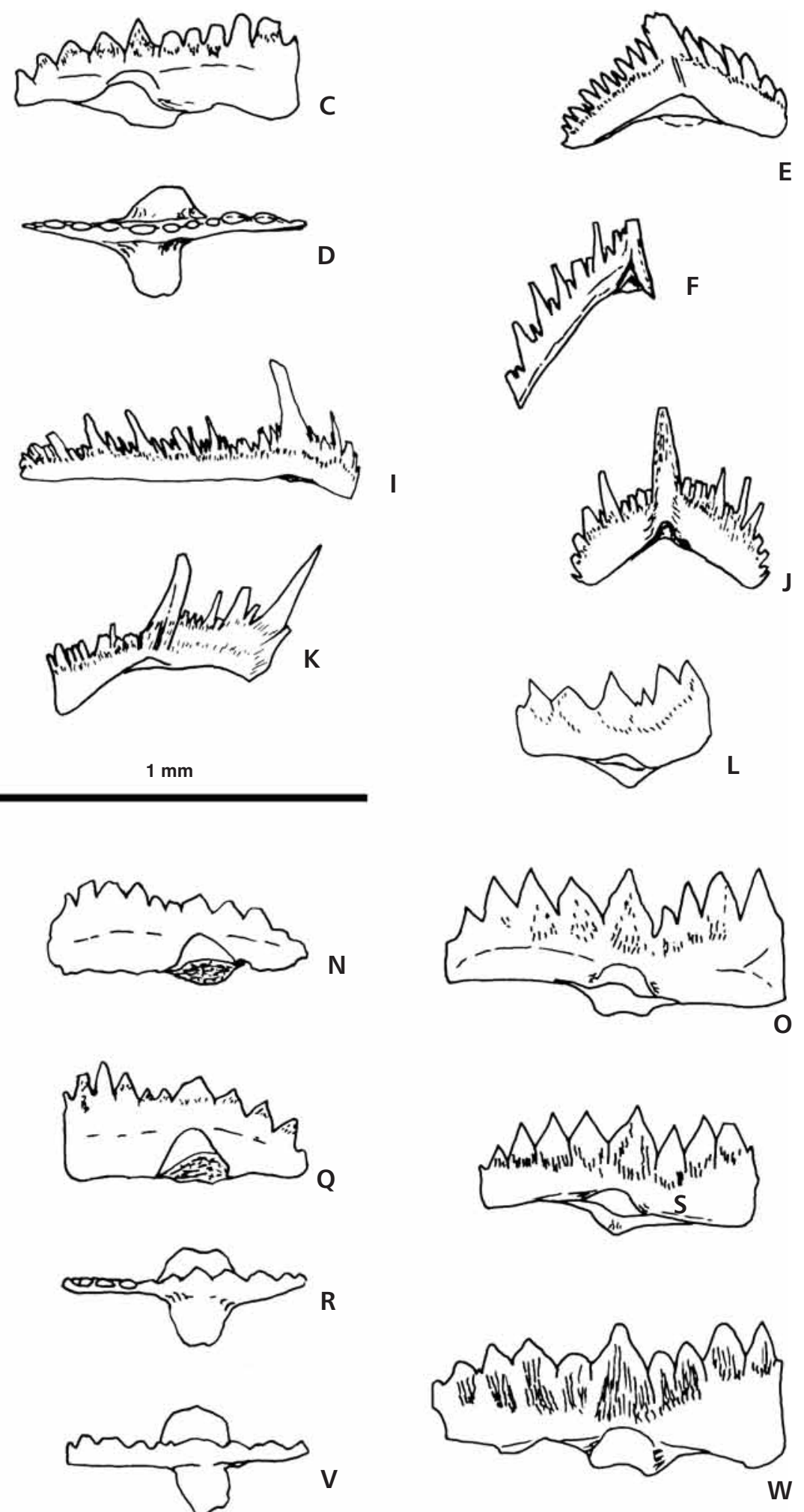
bution that appears closest to the lower Devonian system boundary is I. hesperius Klapper \& Murphy, 1974. A formal woschmidti Zone would begin somewhere within the early half of the Early Lochkovian. Additionally, the age of the type strata of the zonal index Icriodus woschmidti Ziegler, 1960 and of Zieglerodina remscheidensis (Ziegler, 1960), have been implied in complex errors and must be assessed.

When Jeppsson (1988, pp. 26, 27) expressed his opinion that the type strata of Zieglerodina remscheidensis and of Icriodus woschmidti at Untenrüden are of late Silurian age, he assumed that the taxon that he would publish (in 1989) as "Ozarkodina s. remscheidensis (Ziegler, 1960) sensu nov." warranted the correlation between the Silurian beds 11-12 of the Klonk section and the type stratum in the Untenrüden section. Jeppsson (1989, p. 21, pl. 2, figs 6-11) figured Pa elements of this taxon considering them as "an off-shore ecotype of $O$. s. remscheidensis" with "neotenic characters". Irrespective of all biostratigraphical implications, the distinct morphology of the figured $\mathrm{Pa}$ elements cannot warrant a taxonomic identification with $Z$. remscheidensis, nor does the Sa element (Jeppsson 1989, pl. 3, fig. 15) with a rather open angle between both branches suggest an inclusion in the species remscheidensis. This taxon, as characterized by the Pa elements, is a separate species that we erect as Zieglerodina? klonkensis sp. nov.

Jeppsson (1988, pp. 26, 27) compiled several localities, at which Icriodus woschmidti Ziegler, 1960 seems to appear in Silurian horizons. One of these horizons is its type stratum in the section of Untenrüden, measured and sampled by Ziegler (1960). Ziegler stated this section to belong to the "Ockrige Kalke" (= Ochreous Limestones) Member at the base of the Huinghausen Formation. The name of Ockrige Kalke does not imply any relation with the pelagic Thuringian Ockerkalk horizon (= Ochre Limestone). It is a local unit in the Rhenish Facies of shallow waters. In the section, beds a to i were distinguished.

Bed a $(=1)$ furnished the first Warburgella rugosa rhenana $\mathrm{G}$. Alberti, 1962, which indicates a Devonian age of the entire section. Alberti (1962) reported, from the same bed, "incomplete cephala of an A. (Acastella), that are close to A. (Acastella) heberti elsana" R. \& E. Richter, 1954. This trilobite marks the second trilobite zone after the Monograptus uniformis boundary at the beginning of the Devonian. In bed g (=8), G. Alberti found pygidia of "A. (Acastella) tiro?" with initial marginal spines. This feature indicates attribution to an early part of the tiro Zone or to the transition toward this zone. Bed $\mathrm{g}$ is the type stratum of Icriodus wo. woschmidti, and bed e, about $1 \mathrm{~m}$ below bed $\mathrm{g}$, is the type stratum of Zieglerodina remscheidensis. Neither is Silurian. The succession of early Lochkovian Acastella taxa is one of the best controlled phylogenetic lineages in the Lochkovian (compare comments by Gandl
1972). The transition from the elsana to the tiro Zone is found in Celtiberia just above the common type stratum of Icriodus transiens, Icriodus bidentatus, Icriodus rectangularis, Pelekysgnathus elongatus, and Zieglerodina repetitor, which also furnished Ancyrodelloides carlsi (Boersma, 1973) and a somewhat paucidentate Zieglerodina aff. remscheidensis (see Carls \& Gandl 1969, pl. 19, fig. 2). The type stratum of Icriodus wo. woschmidti and probably also that of Zieglerodina remscheidensis are therefore slightly younger than the basal bed of submember d1c gamma of the Luesma Formation in Celtiberia, which bears the conodonts just mentioned. None of these conodonts has ever been found in Silurian beds. Of course, the age of a taxon is not delimited downwards through the age of its type stratum. Nevertheless, it must be taken into account that the index of the traditional first Devonian conodont zone ranges rather high, as compared to the other Devonian taxa just mentioned.

Comparatively old specimens of "Icriodus wo. woschmidti" have been figured by Carls (1975, pl. 2, figs 19-21, from $1 \mathrm{~m}$ below the first Devonian shelly fauna of Celtiberia with Acastella heberti). The old Celtiberian specimens do not exhibit the extreme shapes of transverse ridges that characterize the holotype and the bigger paratypes of Icr. woschmidti. Instead, they have lateral denticles that are better offset and trend morphologically towards other species. Herein, these specimens are regarded to represent results of an early radiation from which several species, including those mentioned above, have developed. In view of this development, the type material of Icr. woschmidti appears as a rather specialized side branch, which corresponds to its younger age.

In the Podolian succession, the entry of Icriodus postwoschmidti Mashkova, 1968, formally the second zonal index of the Lochkovian, is reported from about $15 \mathrm{~m}$ above Monograptus uniformis angustidens that marks the start of the Devonian (Nikiforova 1977, fig. 4). Thus, the range of $I$. postwoschmidti begins within the range of Acastella heberti and almost $100 \mathrm{~m}$ below Acastella tiro. This means that a zonal scheme with a woschmidti and a postwoschmidti Zone according to the restricted indexes would imply uncertainty as to their succession.

The index of the postwoschmidti Zone and I. transiens Carls \& Gandl, 1969 were synonymized (Ziegler 1971, pp. 233-235) and the taxa found together with I. transiens were considered to characterize the postwoschmidti Zone; but the synonymization is refutable and the age relations are not certain, as the origins are unknown. Icriodus hesperius is the named species in Nevada and Bohemia that appears most closely to the beginning of the Devonian. A succession of hesperius Zone and revised postwoschmidti Zone for the interval before Ancyrodelloides carlsi would be more appropriate than the traditional formalisms. 


\section{Systematic descriptions}

Family Spathognathodontidae Hass, 1959

\section{Genus Zieglerodina Murphy et al., 2004}

Type species. - Spathognathodus remscheidensis Ziegler, 1960.

Remarks. - The type species of Zieglerodina has a characteristic Sa element (see Murphy et al. 2004, p. 14). Virtually the same shape is present in Zieglerodina repetitor and in its unnamed successor (= "Ozarkodina" sp. N of Carls 1987 in the lower part of the Nogueras Fm. in Celtiberia). This suggests that the Sa elements can characterize lineages and, thus, may be useful for the subdivision of the genus Zieglerodina s.l. The Sa elements associated to the new species erected herein (whose holotypes are Pa elements) differ from the Sa element found with Zieglerodina remscheidensis. Therefore it might become necessary to attribute the new species to other generic units, when the records have been completed. Therefore the new species are treated as Zieglerodina? At present, Zieglerodina is the genus that would be indicated by $\mathrm{Pb}, \mathrm{M}, \mathrm{Sb}$, and $\mathrm{Sc}$ elements. The range of Zieglerodina s.l. begins in the late Ludfordian, but the new taxa range mainly in the Přídolí. Probably, early Zieglerodina s.l. were derived from Parazieglerodina Carls et al., 2005 through increase in the intercalation of small denticles between the bigger ones on the branches of ramiform elements.

\section{Zieglerodina? ivochlupaci sp. nov. Figures 7A-Y, 8Q-S}

Holotype. - The Pa element cat. No. L38687 (National Museum, Prague) figured on Fig. 7A, B and Fig. 8Q-S.

Type locality. - The Požáry Quarries - the type section of the Přídolí Series.

Type stratum. - Limestone sample No. PZ076 - corresponding to bed No. 133 of the Požáry section according to Kříž et al. (1986, fig. 6), Požáry Formation, $14.5 \mathrm{~m}$ above the Př́idolí GSSP.

Paratypes. - Pa elements (L38688 to L38689, L38695 to L38697).

Additional figured material. - a) Stratotypical: $\mathrm{Pb}$ element L38692, M element L38693, Sc element L38690, Sb element L38691, Sa element L38694. b) From the approximately $5 \mathrm{~cm}$ thick limestone bed PZ078, about $45 \mathrm{~cm}$ above the type stratum (L38698-L38700). c) From Nordic erratic sample Lag Vas 4 found by Peter Laging near Vastorf (Lüneburg), a limestone with Protochonetes furnishing also Delotaxis elegans of the detorta plexus, Pa elements (SMF69975-SMF69979).

Etymology. - Dedicated to the memory of the late Prof. Dr. Ivo Chlupáč, Univerzita Karlova, Prague, the successful biostratigrapher and inspiring researcher of the Barrandian Palaeozoic.

Depositories. - National Museum Prague (Czech Republic), catalogue Nos.: L38687-L38700, Forschungsinstitut und Naturmuseum Senckenberg, Frankfurt a. M., Germany), catalogue Nos: SMF69975-SMF69979.

Diagnosis. - Pa element: Small, paucidentate (about 10-11 denticles), unequidentate, mostly with the following arrangement of denticles: a) 1 anterior "germ" denticle; b) a group of usually 3 higher and stronger denticles, c) commonly 2 smaller ones, d) the cusp, often not high, e) a group of mostly 3 denticles with triangular tips in a sloping line, f) 1-2 small final denticles. Basal lobes small, not ornamented, forming a nearly symmetrical "bell-shaped" vault centered slightly behind midlength and often wider than long (oval outline).

Description. - Pa element: (see diagnosis). There is a difference in the Pa elements from smaller overall size and lower numbers of denticles in the erratic material to higher numbers in sample PZ078: The outer lobe is often more anterior than the inner one, but their shapes are similar.

$\mathrm{Pb}$ element: Pattern of the form taxon Ozarkodina denckmanni Ziegler, 1956. The blade is rather straight in oral view. Commonly it has 6 anterior denticles that are stronger than the posterior ones; the cusp is high and slender; the posterior blade has commonly about 10 denticles with only a few small ones intercalated. The aboral margins form an angle of $135^{\circ}-150^{\circ}$.

$\mathrm{M}$ element: Pattern of the form taxon Neoprioniodus bicurvatus Walliser, 1964; anteriorly 2 feeble denticles may occur.

Sc element: The Sc elements correspond to the traditional parataxon "Hindeodella priscilla" of former concepts. The alternation of denticle sizes is more developed than in the Sb elements. Possibly, there are two pairs; the anterior branch is very short and nearly horizontal in one pair and slightly longer and moderately bent downwards in another pair present in the sample.

$\mathrm{Sb}$ element: The $\mathrm{Sb}$ elements are much stouter and shorter than in the remscheidensis apparatus (= parataxon Plectospathodus alternatus Walliser, 1964). The anterior branch is commonly broken; it seems to be slightly shorter than the posterior one. The element describes a 
continuous bow of only feeble curvatures (lateral and vertical) and does not form a marked angle at the basal cavity. The inner lip of the basal cavity forms a small, slightly vaulted pyramid often recalling the lip of the Sa element. Behind the cusp there are commonly 3 big denticles and in each interspace 1 or 2 (3) small ones; in the posterior end a few denticles are crowded, one of which almost reaches the size of the cusp (this feature is reminiscent of Ozarkodina s.s.).

Sa element: The basal cavity has a round posterior lip forming a rounded and rather short vault. The aboral margins of the branches form angles between $110^{\circ}$ and $135^{\circ}$. Each branch has, in its distal half, about 3 big denticles and more small ones. The groove on the anterior face of the cusp is less pronounced than in the remscheidensis group. The alternation of denticle sizes fades distally, but the outermost denticles decrease in size, diverge increasingly, and describe a sloping arc.

Remarks. - If Zieglerodina? ivochlupaci sp. nov. was a descendant of Parazieglerodina plodowskii, it was probably separated from it by several intermediate taxa; $\mathrm{Pb}$ and $\mathrm{Sb}$ elements are the most similar ones. The similarities with the type species of Zieglerodina in the $\mathrm{Pa}$ element consist in the presence of an anterior group of bigger denticles and in the simple basal lobes.

The $\mathrm{Pb}$ element is shorter than those of the remscheidensis group, but otherwise it differs little. The M element does not distinguish both groups. Differences in the $\mathrm{Sb}$ and Sc are obvious and can contribute to a future generic separation from the remscheidensis group as well as the Sa.

The conodont material obtained from $4.4 \mathrm{~kg}$ of limestone of the type stratum comprised: $66 \mathrm{~Pa}, 21 \mathrm{~Pb}$, over $9 \mathrm{M}, 16 \mathrm{Sc}, 21 \mathrm{Sb}, 6 \mathrm{Sa}$. Although the extraction was not exhaustive and many fragments as well as subordinate numbers of other spathognathodontid elements are present, the material suggests the presence in the apparatus of: $1 \mathrm{Sa}$, 2 pairs of $\mathrm{Sb}, 2$ pairs of $\mathrm{Sc}$, and 1 pair of $\mathrm{M}$ elements. $\mathrm{Pb}$ and $\mathrm{Pa}$ elements exist in a surplus suggesting both higher production and recovery rates. This trend is quite common in Zieglerodina and contrasts with the balances in Wurmiella.

It seems that Z.? ivochlupaci is biostratigraphically significant shortly before the eosteinhornensis Zone s.s. and that it can mark the early part of the range of the Delotaxis detorta plexus in the late part of the early Přídolí.

\section{Zieglerodina? klonkensis sp. nov.}

1989 Ozarkodina steinhornensis remscheidensis (Ziegler, 1960) sensu nov. - Jeppsson, p. 28, pl. 2, figs 6-11; pl. 3 , figs $11-18$.
Holotype. - The Pa element figured by Jeppsson, 1989, pl. 2, fig. 9a-c, LO5897 of the type collection at the Department of Historical Geology and Palaeontology, University of Lund, Sweden.

Type locality. - The GSSP section at Klonk.

Type stratum. - Bed 12, about $2.5 \mathrm{~m}$ below the S/D boundary, late Přídolí.

Paratypes. - Pa element figured by Jeppsson (1989), pl. 2, figs 6 (LO 5895, Klonk bed 11), 8 (LO5896, Klonk bed 12), 10, 11 (LO5898-LO5899, Klonk bed 12).

Additional material. - $\mathrm{M}$ and $\mathrm{S}$ elements figured by Jeppsson (1989), pl. 3, figs 13-18 from Klonk, bed 12 (LO5913-LO5918).

Etymology. - Material of this taxon was first described from the Silurian/Devonian GSSP section of Klonk, Czechia.

Depository. - Department of Historical Geology and Palaeontology, University of Lund, Sweden.

Diagnosis. - Pa element: Zieglerodina? with Pa elements of moderate size, straight and thin blade; about 9 to 10 anterior and 5 to 6 posterior denticles plus low cusp; 4 to 6 denticles in anterior comb with evenly rounded profile, followed by mostly 4 smaller ones sloping toward cusp; posterior denticles slope with curved profile, amid them one or two as strong as cusp; tongue-shaped basal lobes entirely behind mid-length, forming a short but broad vault that is slightly asymmetrical, has narrow but high necks and low flange-like rims, no nodes.

Remarks. - Jeppsson (1989, p. 27) argued that the "O. steinhornensis group (Jeppsson 1975)" had a "marked tendency to form local populations" and "that a large number of contemporaneous populations existed in the Silurian" with "little evidence for these representing distinct lineages... in the gigantic web of a single lineage". This opinion resulted in the present taxon being synonymized in "Ozarkodina steinhornensis remscheidensis" with "adaptation to an offshore environment" and "neotenic aspects". Additionally, its Př́idolí occurrence was mistakenly regarded as coeval with the intra-Lochkovian type stratum of Zieglerodina remscheidensis.

The Sa element figured by Jeppsson (1989, pl. 3, fig. 15) differs moderately but clearly from the figured ones in the type material of the taxon remscheidensis (Ziegler 1960, pl. 15, figs 1,2); it is broader and has a wider angle between the branches, which contributes to the specific differences. 

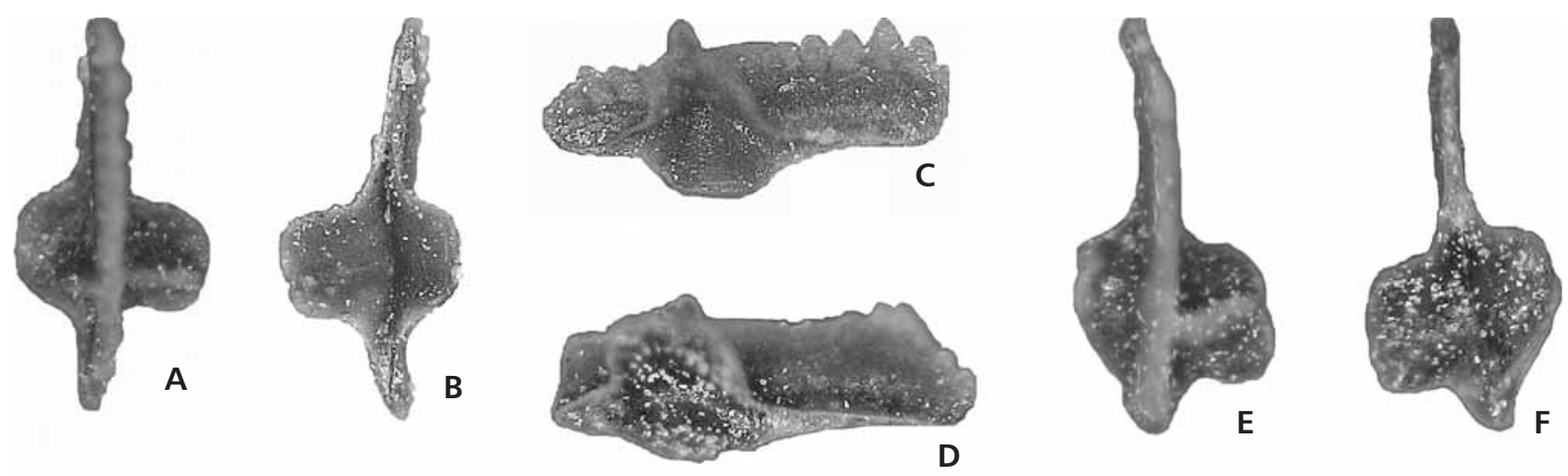
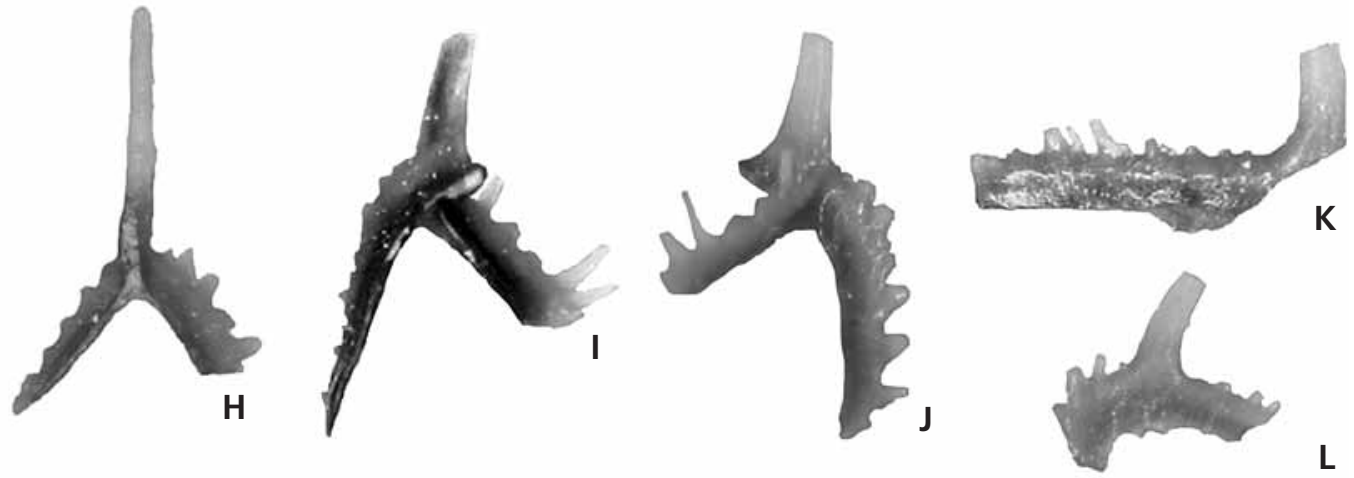

$1 \mathrm{~mm}$
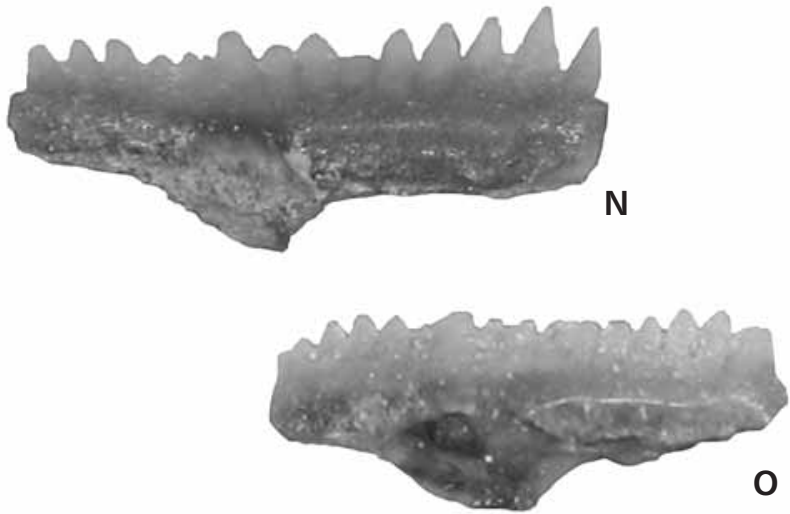

M
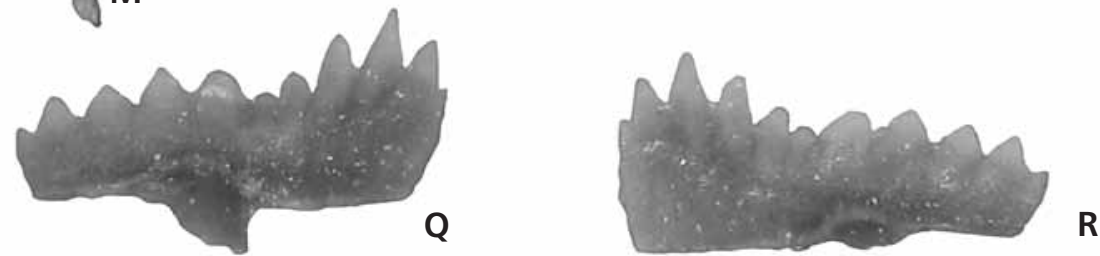

$\mathbf{R}$

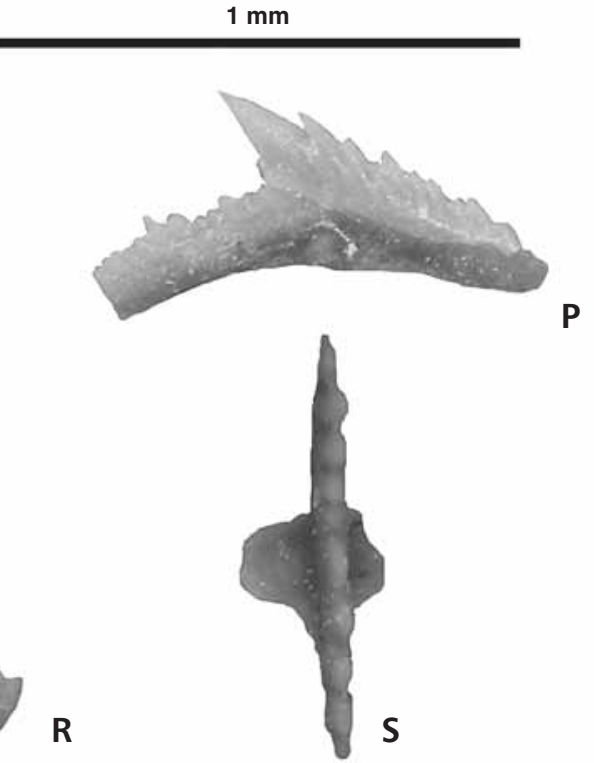

Figure 8. Digital camera pictures; specimens uncoated - gen. W eosteinhornensis (A-F), Delotaxis detorta (G-H, K-L), Delotaxis sp. (I-J), Zieglerodina? zellmeri sp. nov. (M-P), Zieglerodina? ivochlupaci sp. nov. (Q-S). • A-C - gen. W eosteinhornensis, Pa element, cat. No. L38682, Požáry section, sample PZ083, A - upper view, B - lower view, C - outer lateral lower view. • D-F - gen. W eosteinhornensis, Pa element, cat. No. L38683, Požáry section, sample PZ083, D - outer lateral view, E - upper view, F - lower view. • G, H - Delotaxis detorta, incomplete Sa, cat. No. L38675, Požáry section, sample PZ076, G - anterior view, H - posterior view. •I, J - Delotaxis sp., a strongly angular Sb element, cat. No. L38678, Požáry section, sample PZ076, same as Fig. 3I, I - outer lateral view, J - inner lateral view. $\bullet$ K - Delotaxis detorta, incomplete Sc element, cat. No. L38677, Požáry section, sample PZ076, same as Fig. 3E, lateral view. $\bullet$ L - Delotaxis detorta, Sc element, cat. No. L38679, Požáry section, sample PZ076, same as Fig. 3M, outer lateral view. $\bullet$ M-P - Zieglerodina? zellmeri sp. nov., Pa element (holotype), cat. No. L38684, Požáry section, sample PZ030, M - upper view, N - outer lateral view, O - Pa element (paratype), cat. No. L38685, Požáry section, sample PZ030, outer lateral view, P - Pb element, cat. No. L38686, Požáry section, sample PZ030, same as Fig. 6G, outer lateral view. $\bullet$ Q-S - Zieglerodina? ivochlupaci sp. nov., Pa element (holotype), cat. No. L38687, Požáry section, sample PZ076, Q - outer lateral view, R - inner lateral view, S - upper view. 
Jeppsson has described and figured the Klonk material so that no additional morphological details have to be added.

Stratigraphic position. - In the Požáry section, Z.? klonkensis is currently known from $13 \mathrm{~m}$ to about $3 \mathrm{~m}$ below the Silurian/Devonian boundary; in the Klonk section it ranges within the late Př́dolí (Jeppsson 1988, tab. 1). Its absence from the EOL suggests a gap in the late Přídolí.

\section{Zieglerodina? zellmeri sp. nov.}

Figures 6A-G, J-N, 8M-P

1971 Spathognathodus steinhornensis eosteinhornensis Walliser 1964. - Bultynck \& Pelhate, pl. 1, fig. 2a, b (non figs 1, 3); Fig. 2, B1.

1983 Spathognathodus steinhornensis eosteinhornensis Walliser, 1964. - Viira, text.-fig. 4, samples $67.40 \mathrm{~m}$ and $64.65 \mathrm{~m}$ (basal Äigu beds).

1998 Ozarkodina remscheidensis eosteinhornensis (Walliser, 1964) sensu lato. - Viira \& Aldridge, pl. 4, figs 13-15 (14 and 15 from basal Äigu beds with late "Ozarkodina" parasnajdri).

Holotype. - The Pa element cat. No. L38684 figured on Figs 6A, B, 8M, N.

Paratype. - The Pa element cat. No. L38685 figured on Figs 6F, 8O.

Additional material. - a) stratotypical $\mathrm{Pb}$ element cat. No. L38686 figured on Figs 6G, 8P, b) from the erratic boulder L1 from Vastorf near Lüneburg: 2 Pa (SMF69984 figured on Fig. 6K, L; SMF69986 figured on Fig. 6N), $1 \mathrm{~Pb}$ (SMF69985 figured on Fig. 6M), 1 Sa (SMF69981 figured on Fig. 6D), 1 Sb (SMF69982 figured on Fig. 6E), 1 Sc (SMF69980 figured on Fig. 6C), 1 M (SMF69983 figured on Fig. 6J).

Depositories. - National Museum Prague (Czech Republic), catalogue Nos.: L38684-L38686. Forschungsinstitut und Naturmuseum Senckenberg, Frankfurt a. M., Germany), catalogue Nos: SMF69980-SMF69986.

Type locality. - The Požáry Quarries - the type section of the Př́idolí Series.

Type stratum. - Limestone sample No. PZ030 - corresponding to old bed No. 96 (basal bed of the Přídolí) of the Požáry section according to Kříž et al. (1986, fig. 6), Požáry Formation, Př́idolí.

Etymology. - After Dr. Henning Zellmer, formerly Techni- cal University of Braunschweig, who furnished the conodonts of sample L1, a Nordic erratic boulder.

Diagnosis. - (Mature Pa element): Pa big, long, low, multidentate (close to 15 denticles), rather equidentate, with nearly straight aboral margins (lateral view) and little lateral curvature, rather horizontal oral margin with moderate slope near posterior end; unornamented basal lobes with bell-shaped vault centered slightly behind midlength; white matter scarce, not reaching deeply into blade.

Description. - The apparatus of Zieglerodina? zellmeri is close to that of Zieglerodina, but distant from gen. W eosteinhornensis. The Pa element reaches over $1.1 \mathrm{~mm}$ length; it is rather straight and low, equidentate, often with 14 or over 15 denticles that have scarce white matter mainly near the tips; it has a bell-shaped basal cavity centered closely behind mid-length and lateral thickenings of only moderate strength. Denticles adjacent to the cusp are often small, but commonly the cusp does not protrude strongly. Associated spathognathodontan $\mathrm{Pb}$ elements resemble the parataxon "Ozarkodina denckmanni" with a low and long posterior branch (contrasting with the short $\mathrm{Pb}$ element of gen. W eosteinhornensis) and have a protruding cusp that can incorporate neighbouring denticles. The $\mathrm{M}$ elements correspond to the parataxon "Neoprioniodus bicurvatus", are long, equidentate, and hardly have germs of anterior denticles. The prevailing Sa element, which probably belongs to this taxon, is broadly winged with an angle of $120^{\circ}$ to $130^{\circ}$ between both branches; it has 6 to 9 stronger denticles on each branch and some intercalated small ones; it is much wider than its homologues in Zieglerodina s.s. and gen. W eosteinhornensis. The Sb element resembles that of Zieglerodina in its inconspicuous basal cavity and in the gentle and even curvature of the blade without a marked angle. The denticles of Sb and Sc elements alternate intensely in size. The anterior branch of the Sc element is horizontal and moderately incurved and bears about 8 big denticles and a few intercalated small ones; the long posterior bar is feebly undulated, and slight lateral thickenings cause rounded ledges below the denticles on both sides.

Remarks. - The equidentate aspect of the Pa element has induced former workers to consider this taxon as belonging to the index eosteinhornensis. With the exception of a single $\mathrm{Pa}$ element from the type bed that has a steep ridge along the outer side of its cusp and is rather a malformation, we have not seen the ornamentation of the basal lobe(s) nor their more posterior position and larger outlines that characterize gen. W eosteinhornensis as well as welded denticles. Reference of these specimens to eosteinhornensis is considered unwarranted.

The widely expanded branches of the Sa element may 
constitute a means to separate the taxon zellmeri from Zieglerodina, when more insight is available.

The stratigraphic positions of the Baltic material are close to the base of the Äigu Member (k3b ̈̈) of the Kaugatuma Fm. in Estonia just before the end of "Ozarkodina" parasnajdri. The position at the beginning of the Přídolí in the Požáry section, just above the end of " $O$ ". crispa, corroborates the common correlation of the Estonian sections with the Barrandian standard.

\section{Conclusions}

1. The late Silurian and Early Lochkovian development of spathognathodontan and icriodontid conodont taxa requires a more detailed taxonomic subdivision than has been practised hitherto. Biostratigraphical conclusions must not only rely on conodonts against other evidence.

2. The eosteinhornensis Zone s.s. begins amid the Přídolí; it is not demonstrable in the Baltic outcrops regions (Scania-Gotland-Estonia).

3. The Delotaxis detorta plexus begins before the eosteinhornensis Zone and it is not limited to the final Přídolí. In the Baltic and in the Požáry section its entry is closely associated to Zieglerodina? ivochlupaci sp. nov. A corresponding formal zone is not recommended. The assumed limitation of a "detorta Zone" to the final Př́idolí is refuted.

4. Zieglerodina? zellmeri sp. nov. begins in the range of "Oz." crispa close to the Ludlow-Přídolí boundary in the East Baltic, in the Armorican Massif and at Požáry. Several early reports of the eosteinhornensis Zone correspond to it.

5. Zieglerodina? klonkensis sp. nov. is erected for a taxon found by Jeppsson $(1988 ; 1989)$ but originally included in Zieglerodina remscheidensis. Z. remscheidensis ranges only within the Early Lochkovian.

6. The radiative development of the genus Icriodus s.l. near the beginning of the Devonian is intense but is still incompletely known. The type stratum of the very particular Icriodus woschmidti is much younger than the entry of Icriodus postwoschmidti in Podolia. A succession of a woschmidti Zone and a postwoschmidti Zone in the Early Lochkovian is not appropriate. The widespread Icriodus hesperius marks the beginning of the Devonian very closely; a zone near the beginning of the Devonian should bear its name instead of the name woschmidti Zone. A postwoschmidti Zone would require a revised characterization.

\section{Acknowledgements}

The Alexander von Humboldt Foundation awarded a fellowship to Ladislav Slavík and supported his stay at Technische Universität
Braunschweig. The study was partly developed with the support of the Institute of Geology ASCR, v.v.i. (Institutional project: AV0Z30130516). The final stage of the study was supported by the Grant agency of the ASCR (project No. B300130613). Peter Laging, Scharnebeck/Lüneburg has provided several erratic limestone boulders of Baltic provenance - we thank him kindly. A former draft of this article was read critically by Richard Aldridge and Svend Stouge; Ruth Mawson provided constructive criticism for the present article. We have profited greatly from their comments and thank them kindly. Responsibility for remaining inadequacies is, of course, ours.

\section{References}

Alberti, G. 1962. Unterdevonische Trilobiten aus dem Frankenwald und Rheinischen Schiefergebirge (Ebbe- und Remscheider Sattel). Geologisches Jahrbuch 81, 135-156.

AldRIDGe, R.J. \& SCHÖNLAUB, H.P. 1989. Conodonts. In HolLAND, C.H. \& BASSETT, M.G. (eds) A Global Standard for the Silurian System. National Museum of Wales, Geological Series 9, 274-279.

Aldridge, R.J., Dorning, K.J., Hill, P.J., Richardson, J.B. \& SivETER, D.J. 1979. Microfossil distribution in the Silurian of Britain and Ireland. In HARris, A.L., Holland, C.H. \& LEAKE, B.E. (eds) The Caledonides of the British Isles, Geological Society of London, Special Publication 8, 433-438.

BARNETT, S.G. 1971. Biometric determination of the evolution of Spathognathodus remscheidensis: A method for precise intrabasinal time correlations in the northern Appalachians. Journal of Paleontology 45, 274-300.

BARNETT, S.G. 1972. The evolution of Spathognathodus remscheidensis in New York, New Jersey, Nevada, and Czechoslovakia. Journal of Paleontology 46, 900-917.

BARRICK, J.E. \& KLAPPER, G. 1992. Late Silurian-Early Devonian Conodonts from the Hunton Group (Upper Henryhouse, Haragan, and Bois d'Arc Formations), South-Central Oklahoma. Oklahoma Geological Survey Bulletin 145, 19-65.

Bischoff, G.C.O. \& Sannemann, D. 1958. Unterdevonische Conodonten aus dem Frankenwald. Notizblatt des Hessischen Landesamtes für Bodenforschung 86, 87-110.

Boersma, K.T. 1973. Description of certain Lower Devonian platform conodonts of the Spanish central Pyrenees. Leidse Geologische Mededeelingen 49, 285-301.

Branson, E.B. \& Mehl, M.G. 1933. Conodonts from the Bainbridge (Silurian) of Missouri. University of Missouri Studies 8, 39-53.

Bultynck, P. 1971. Le Silurien Supérieur et le Dévonien Inférieur de la Sierra de Guadarrama (Espagne Centrale); Deuxième partie: Assemblages de Conodontes a Spathognathodus (1). Bulletin de l'Institut Royal des Sciences Naturelles de Belgique 47, 1-43.

Bultynck, P. \& Pelhate, A. 1971. Découverte de la Zone a eosteinhornensis (Conodontes) dans le Synclinorium Médian du Massif Armoricain. Mémoire du B.R.G.M. 73: Colloque ordovicien-silurien, 189-197. 
CARLS, P. 1975. Zusätzliche Conodonten-Funde aus dem tieferen Unterdevon Keltiberiens (Spanien). Senckenbergiana Lethaea 56, 399-428.

CARLS, P. 1987. Ein Vorschlag zur biostratigraphischen Redefinition der Grenze Gedinnium/Siegenium und benachbarter UnterStufen. Courier Forschungs-Institut Senckenberg 92, 77-121.

CARLS, P. \& GANDL, J. 1969. Stratigraphie und Conodonten des Unter-Devons der östlichen Iberischen Ketten (NE Spanien). Neues Jahrbuch für Geologie und Paläontologie Abhandlungen 132, 155-218.

CARls, P., Slavík, L. \& VAlenzuela-Ríos, J.I. 2005. A new Ludlow (Late Silurian) Spathognathodontidae (Conodonta) from Bohemia with incipient alternating denticulation. Neues Jahrbuch für Geologie und Paläontologie Monatshefte 9, 547-565.

COOPER, B.J. 1980. Towards an improved Silurian conodont biostratigraphy. Lethaia 13, 209-227.

GANDL, J. 1972. Die Acastavinae und Asteropyginae (Trilobita) Keltiberiens (NE-Spanien). Abhandlungen der Senckenbergischen Naturforschenden Gesellschaft 530, 1-184.

JEPPSSON, L. 1972. Some Silurian conodont apparatuses and possible conodont dimorphism. Geologica et Palaeontologica 6, 51-68.

JEPPSSON, L. 1974. Aspects of Late Silurian conodonts. Fossils and Strata 6, 1-54.

JEPPSSON, L. 1988. Conodont biostratigraphy of the Silurian-Devonian boundary stratotype at Klonk, Czechoslovakia. Geologica et Palaeontologica 22, 21-31.

JEPPSSON, L. 1989. Latest Silurian conodonts from Klonk, Czechoslovakia. Geologica et Palaeontologica 23, 21-37.

JePpsson, L. \& MerRILl, G.K. 1982. How best to designate obsolete taxonomic names and concepts: examples among conodonts. Journal of Paleontology 56, 1489-1493.

Jeppsson, L., ViIRA, V. \& MÄNnIK, P. 1994. Silurian conodont-based correlations between Gotland (Sweden) and Saaremaa (Estonia). Geological Magazine 131, 201-218.

Klapper, G. \& Murphy, M.A. 1974. Silurian-Lower Devonian conodont sequences in the Roberts Mountains Formation of central Nevada. University of California Publications in Geological Sciences 111, 1-62.

KLEFFNER, M.A. 1989. A conodont based chronostratigraphy. Bulletin of the Geological Society of America 101, 904-912.

Kříž, J., JAEGER, H., PARIS, F. \& SCHÖNLAUB, H.P. 1986. Přídolí - the fourth subdivision of the Silurian. Jahrbuch der Geologischen Bundesanstalt 129, 291-360.

Mashkova, T.V. 1968. Conodonts of the genus Icriodus Branson et Mehl (1938) from Borshchov and Skala horizons of Podolia. Doklady Akademii nauk, Earth Sciences 182, 220-233.

Mehrtens, C.J. \& BARnetT, S.G. 1976. Conodont subspecies from the Upper Silurian-Lower Devonian of Czechoslovakia. Micropaleontology 22, 491-500.

Murphy, M.A. \& VAlenzuelA-Ríos, J.I. 1999. Lanea new genus, lineage of Early Devonian conodonts. Bolletino della Societa Paleontologica Italiana 37, 321-334.

Murphy, M.A., Valenzuela-Ríos, J.I. \& CARls, P. 2004. On Classification of Pridoli (Silurian)-Lochkovian (Devonian)
Spathognathodontidae (Conodonts). University of California, Riverside Campus Museum Contribution 6, 1-25.

Nikiforova, O. 1977. Podolia. In Martinsson, A. (ed.) The Silurian-Devonian Boundary, I.U.G.S. Series A 5, 52-64.

REXroAD, C.B. \& Craig, W.W. 1971. Restudy of conodonts from the Bainbridge Formation (Silurian) at Lithium, Missouri. Journal of Paleontology 45, 684-703.

RHODES, F.H.T. 1953. Some British Lower Palaeozoic conodont faunas. Philosophical Transactions of the Royal Society of London, Series B: Biological Sciences 237, 261-328.

RiCHTER, R. \& RichteR, E. 1954. Die Trilobiten des Ebbe-Sattels und $\mathrm{zu}$ vergleichende Arten (Ordovizium, Gotlandium/Devon). Abhandlungen der Senckenbergischen Naturforschenden Gesellschaft 488, 1-62.

UYENO, T.T. 1981. Stratigraphy and conodonts of the Upper Silurian and Lower Devonian rocks in the environs of the Boothia Uplift, Canadian Arctic Archipelago. Part II, Systematic study of conodonts. Geological Survey of Canada Bulletin 292, 39-75.

VIIRA, V. 1983. Paleontologya drevnego paleozoya pri Baltiky i Podolii. Akademiia nauk Estonskoy SSR, Institut geologii, 41-71.

VIIRA, V. 1999. Late Silurian conodont biostratigraphy in the northern East Baltic. Bolletino della Società Paleontologica Italiana 37, 299-310.

VIIRA, V. 2000. Latest Silurian (Ohesaare Stage) conodonts and the detorta Zone in the Northeastern Baltic. Proceedings of the Estonian Academy of Sciences, Geology 49, 44-62.

VIIRA, V. \& ALDRIDGE, R.J. 1998. Upper Wenlock to Lower Pridoli (Silurian) conodont biostratigraphy of Saaremaa, Estonia, and a correlation with Britain. Journal of Micropalaeontology 17, 33-50.

WALLISER, O.H. 1957. Conodonten aus dem oberen Gotlandium Deutschlands und der Karnischen Alpen. Notizblatt des hessischen Landesamtes für Bodenforschung Heft 85, 28-52.

WALLiSER, O.H. 1960. Scolecodonts, Conodonts and Vertebrates. In Boucot, A.J., Martinsson, A., Thorsteinsson, R., Walliser, O.H., Whittington, H.B. \& Yochelson, E. (eds) A late Silurian fauna from the Sutherland River Formation, Devon Island, Canadian Arctic Archipelago. Geological Survey of Canada Bulletin 65, 21-39.

WALLISER, O.H. 1964. Conodonten des Silurs. Abhandlungen des Hessischen Landesamtes für Bodenforschung, Heft 41, 1-106.

Walliser, O.H. 1972. Conodont Apparatuses in the Silurian. Geologica et Palaeontologica SB1, 75-80.

WolsKa, Z. 1969. Konodonty z wiercenia Chełm (Conodonts from a boring in Chełm, Poland). Acta Palaeontologica Polonica 14, 577-594.

ZIEGLER, W. 1956. Unterdevonische Conodonten, insbesondere aus dem Schönauer und dem Zorgensis-Kalk. Notizblatt des Hessischen Landesamtes für Bodenforschung, Heft 84, 93-106.

ZIEGLER, W. 1960. Conodonten aus dem Rheinischen Unterdevon (Gedinnium) des Remscheider Sattels (Rheinisches Schiefergebirge). Paläontologische Zeitschrift 34, 169-201.

ZIEGLER, W. 1971. Conodont Stratigraphy of the European Devonian. Geological Society of America Memoir 127, 227-284. 